\title{
The South Ecuador subduction channel: Evidence for a dynamic mega-shear zone from 2D fine-scale seismic reflection imaging and implications for material transfer
}

\author{
J.-Y. Collot, ${ }^{1}$ A. Ribodetti, ${ }^{1}$ W. Agudelo, ${ }^{2}$ and F. Sage ${ }^{3}$ \\ Received 8 April 2010; revised 9 August 2011; accepted 24 August 2011; published 10 November 2011.
}

[1] Tectonic processes that control the transition from poorly consolidated sediment entering the subduction channel (SC) to the seismogenic zone are documented using seismic imaging. We applied pre-stack depth migration and a post-processing sequence to a seismic reflection line acquired across the Ecuador convergent margin to obtain a 2D-quantitative image of the first $\sim 24 \mathrm{~km}$ of the SC. Structural interpretation shows that the SC consists of a 630-1150-m-thick, low-velocity, continuous sheet of sediment that dips $\sim 6^{\circ}$ landward and undergoes shear deformation. The long sheet is bounded at top and bottom by décollement thrusts, and developed over time Riedel shears and basal thrust faulting and folding downdip, pointing to a dynamic mega-shear zone. Modeling the strong uppermost and basal SC reflectors reveals that they are associated with 40-80-mthick, $50-350 \mathrm{~m} / \mathrm{s}$, low-velocity perturbations layers inferred to be fluid rich and mechanically weak. A fine-scale velocity model shows two anomalously low-Vp areas in the long sheet, advocating patches of over-pressured fluids. Evidence for Vp variations along the upper-plate foundation suggests either underplated bodies or a fluid-damage zone. A simple temporal reconstruction indicates that underthrusting the long sheet initiated $>450 \mathrm{kyr}$ ago and interrupted $\sim 54 \pm 13 \mathrm{kyr}$ ago, when frontal accretion resumed. During this transient evolution, the SC boundaries revealed highly unstable as most of the $\mathrm{SC}$ was underplated while down going plate material may have been sheared off and incorporated to the SC.

Citation: Collot, J.-Y., A. Ribodetti, W. Agudelo, and F. Sage (2011), The South Ecuador subduction channel: Evidence for a dynamic mega-shear zone from 2D fine-scale seismic reflection imaging and implications for material transfer, J. Geophys. Res., 116, B11102, doi:10.1029/2011JB008429.

\section{Introduction}

[2] The nature of the subduction plate boundary zone has remained a puzzling matter that requires a better understanding of the parameters controlling the transition from soft sediment entering subduction to a strongly coupled fault zone capable of generating the greatest earthquakes on earth [Hyndman et al., 1997; Kanamori, 1986; Pacheco et al., 1993; Tichelaar and Ruff, 1993]. Poorly consolidated sediment, rapidly buried between two strong plates, was proposed to act as a viscous, lubricating layer called the subduction channel (SC), which transmits the velocity and stress fields between the two plates [England and Holland, 1979; Shreve and Cloos, 1986; Cloos and Shreve, 1988a, 1988b; Mancktelow, 1995]. The SC updip segment was then

\footnotetext{
${ }^{1}$ Université de Nice Sophia-Antipolis, Institut de Recherche pour le Développement (UR082), Observatoire de la Côté d'Azur, Géoazur, Villefranche-sur-Mer, France.

${ }^{2}$ ECOPETROL, Instituto Colombiano del Petróleo, Piedecuesta, Colombia.

${ }^{3}$ Université de Nice Sophia-Antipolis, Université Pierre et Marie Curie, Observatoire de la Côte d'Azur, Géoazur, Villefranche-sur-Mer, France.

Copyright 2011 by the American Geophysical Union. 0148-0227/11/2011JB008429
}

considered very weak and aseismic [Byrne et al., 1988], and is further inferred to have a velocity-strengthening behavior during the co-seismic slip [Scholz, 1998; Wang and $\mathrm{Hu}$, 2006].

[3] Multichannel seismic reflection (MCS) images indicate that the interplate sedimentary layer, frequently inferred to be the SC, consists of a relatively low $\mathrm{P}$ wave velocity (Vp), up to $\sim 2 \mathrm{~km}$-thick, stratified layer bounded at top and bottom by strong reflectors. The upper reflector commonly shows a negative polarity, and is usually interpreted as the inter-plate décollement thrust [Aoki et al., 1985; Bangs et al., 2004, 2009; Calahorrano et al., 2008; Park et al., 2002; Sage et al., 2006; Shipley et al., 1992; Tsuru et al., 2002; von Huene et al., 1994].

[4] Drilling data collected at the tip of the Nankai [Taira et al., 1992], Barbados [Moore et al., 1998], and Costa Rica [Kimura et al., 1997] margins show that shear localizes along a very low strength décollement zone, and that sediment below the décollement remains undeformed suggesting that the décollement is a sharp discontinuity in stress transmission [Taira et al., 1992] [Ujiie et al., 2003; Vannucchi and Tobin, 2000]. In the conventional view, the $\mathrm{SC}$ is mechanically decoupled from the overlying wedge so that, near its inlet, underthrust sediments are subject to a 


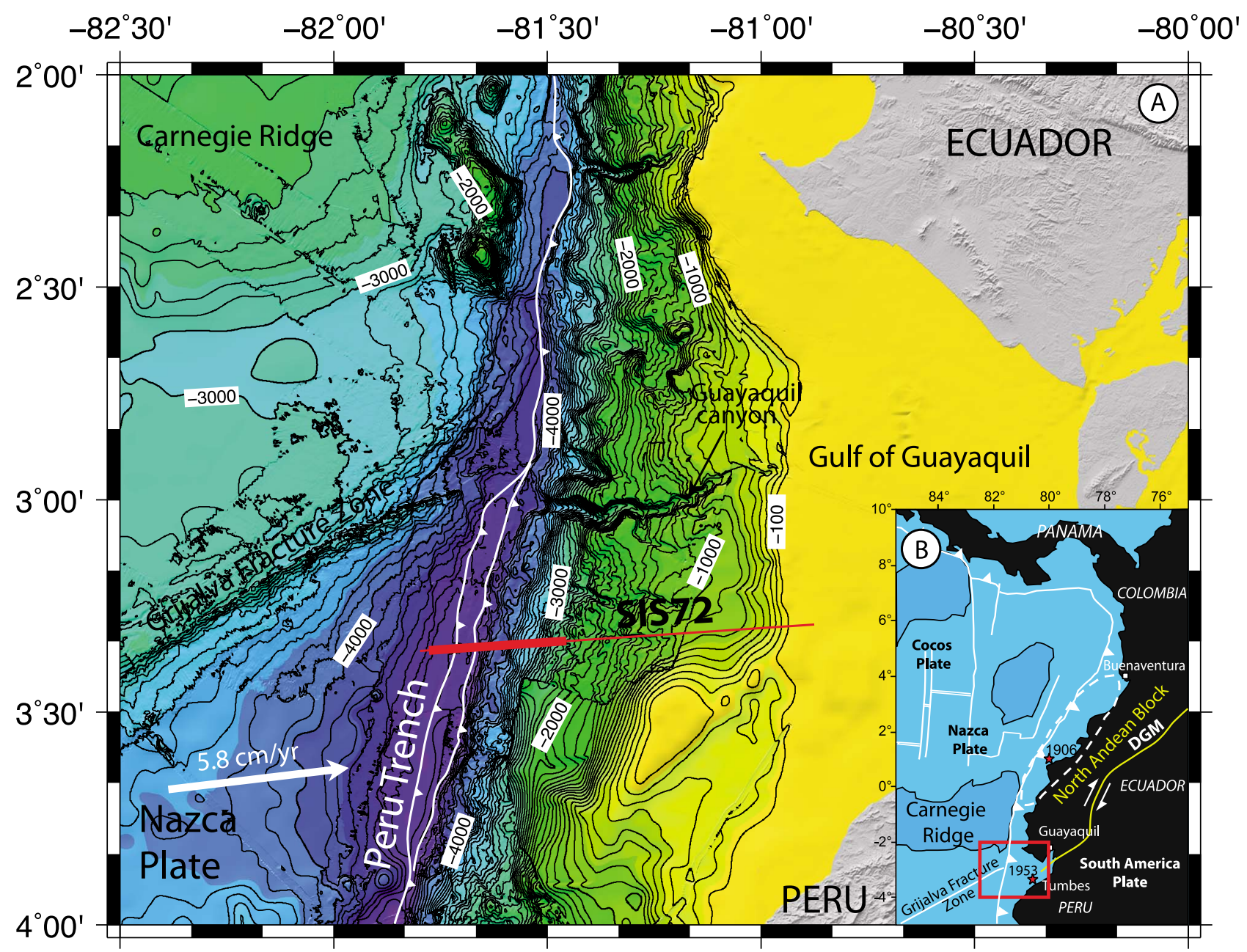

Figure 1. (a) Bathymetric map of the south Ecuador-Nord Peru margin [after Michaud et al., 2006] contoured at $100 \mathrm{~m}$ intervals with the location of Multichannel Seismic reflection line SIS-72. Heavy red line is reprocessed interval of Line SIS-72 shown in Figure 2. White arrow is the predicted Nazca plate convergence rate with respect to South America [Kendrick et al., 2003]. Barbed lines show the deformation front and narrow accretionary wedge [Collot et al., 2002; Calahorrano, 2005]. (b) Location of study area; DGM = Dolores Guayaquil Megashear [Campbell, 1974; Ego et al., 1996]; red stars are earthquakes epicenters [Swenson and Beck, 1996] (see also SISRA catalog); white dash line is 1906 earthquake rupture zone [Kelleher, 1972].

vertical Maximum Principal Stress. This supposition is supported by the progressive densification and thinning of lithologic units between drill sites in the trench and those at the margin tip [Kimura et al., 1997; Saffer, 2003; Vannucchi and Tobin, 2000].

[5] Documenting the strain pattern, fluid circulation, as well as sediment transformation with continued underthrusting toward the seismogenic zone is critical because they are thought to control the aseismic-seismic transition and the décollement dynamics i.e., underplating and tectonic erosion [Shreve and Cloos, 1986]. At modern subduction zones, the detailed structures of the SC as well as the processes governing sediment transformation and shear localization are poorly constrained because of the lack of deep drilling and the poor spatial resolution of seismic data. Numerical models based on best available measurements, empirical laws and laboratory experiments were used to estimate the controls on the aseismic - seismic transition along the plate interface. A suite of processes including lithification, diagenesis, metamorphism, fluid overpressure, pressure solution, frictional velocity dependence, and shear localization is typically inferred to govern this transition [Hyndman and Wang, 1995; Moore and Saffer, 2001; Saffer, 2003; Saffer and Marone, 2003; Screaton, 2006; Vrolijk, 1990].

[6] Direct observations of sparse exhumed SC or equivalents [Kitamura et al., 2005] bring important observations on the SC nature, deformation and fluid cycle. Vannucchi et al. [2008] showed that the entire material involved in a fossil interplate shear zone studied in the Northern Apennines came from the over-riding plate, whereas incoming plate sediment was thrust undeformed beneath a basal décollement. Therefore, on one hand the SC may be viewed as a shear zone from field or drilling data, thus defining the SC in the stricter sense of the term (SC s. s.), and on the other hand, as the interplate low-velocity sediment 


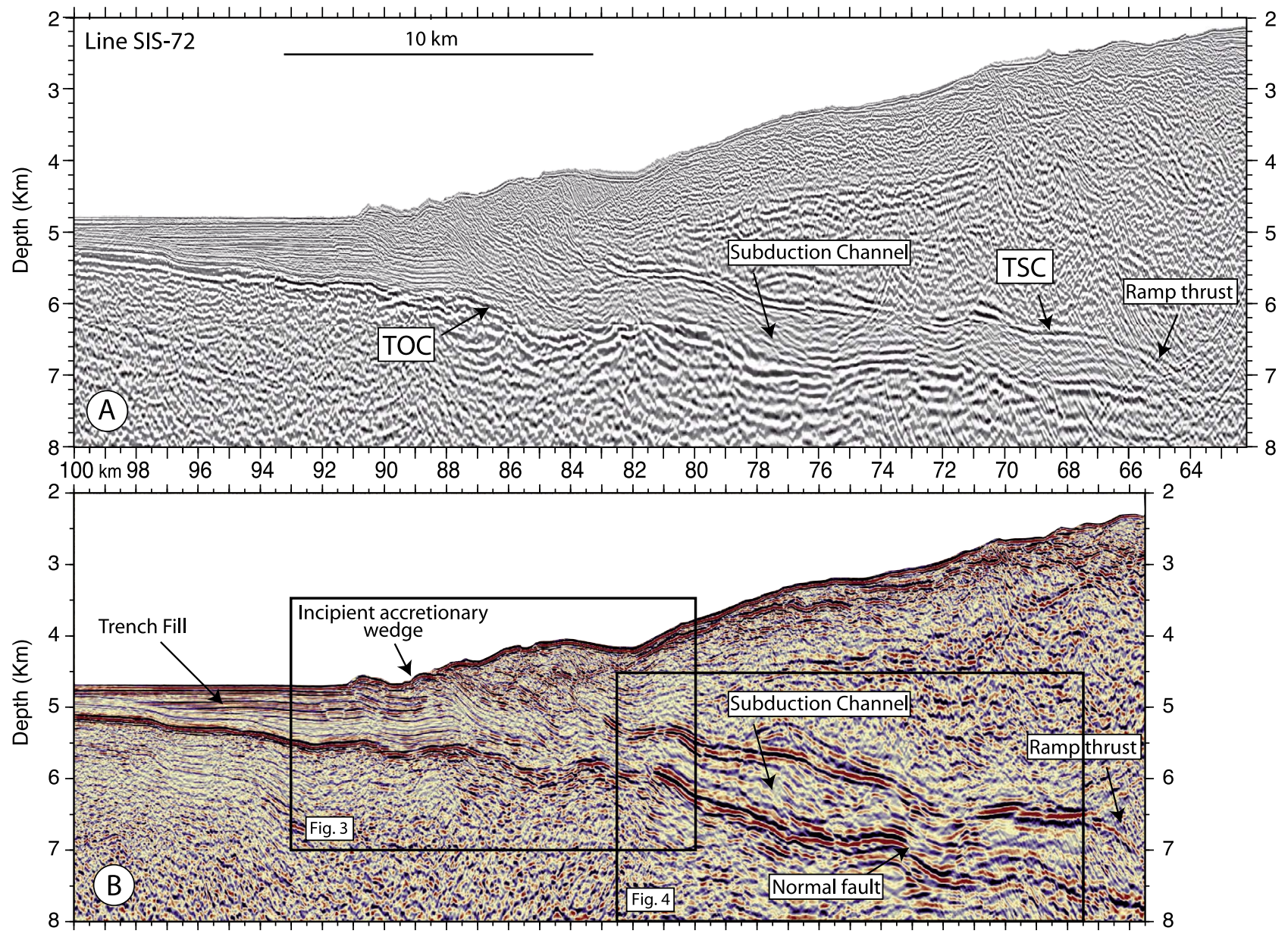

Figure 2. Prestack depth-migrated (PSDM) MCS line SIS-72: (a) PSDM image based on the Kirchhoff algorithm and a 2D velocity model obtained by focusing analysis and iterative velocity picking; TOC = Top of Oceanic Crust reflector; TSC = Top of Subduction Channel reflector [after Calahorrano et al., 2008]. (b) PSDM calibrated image obtained by Iterative ray + Born waveform migration/inversion [Ribodetti et al., 2011]. Note the difference in thickness and dip of the subduction channel and the finer resolution in the channel and accretionary wedge.

layer based on MCS data, hence characterizing the SC in the broader sense (SC b. s.). These SC concepts do not necessarily overlap [Vannucchi et al., 2011]. From the combination of geophysical imaging and geological data, the SC can be defined as a dynamic, finite width interplate shear zone that accommodates both viscous deformation and distributed slip [Vannucchi et al., 2011]. Nevertheless, for consistency with previous literature, we keep using the generic term SC b. s. to designate the seismically imaged interplate sediment layer, no matter what the sediment origin, but knowing that the shear zone, i.e., the SC s. s., may not affect this layer but only bound it.

[7] Imaging the $\mathrm{SC}$ at the best possible resolution, and analyzing the physical properties of its seismic reflector is a pre-requisite to place new constraints on the structural evolution of the SC and on the stability of its boundaries. In this paper, we reprocessed MCS line SIS-72 that was collected across the Ecuador subduction zone (Figure 1a) to tentatively resolve structural details of the spectacular updip segment of the SC off the Gulf of Guayaquil (Figure 2a) [Calahorrano et al., 2008]. We applied pre-stack depth migration/inversion (PSDM) and a post-processing sequence to obtain a 2D quantitative image of the first $24 \mathrm{~km}$ of the SC (Figure 2b). We seek to discriminate tectonic deformation from preserved sedimentary architecture within the SC, distinguish whether and where the deformation is distributed or localized, identify levels where pressured fluids tend to accumulate, and lastly reconstruct the recent tectonic history of the SC along line SIS-72.

\section{Geodynamic Context}

[8] In Ecuador, permanent deformation due to the $5.8 \mathrm{~cm} / \mathrm{yr}$ eastward subduction of the Nazca plate [Kendrick et al., 2003; Trenkamp et al., 2002] causes the opening of the Gulf of Guayaquil [Deniaud et al., 1999; Witt et al., 2006] in relation to the $\sim 6 \mathrm{~mm} / \mathrm{yr}$, northeastward motion of North Andean Block (NAB) along the Dolores-Guayaquil Megashear 
(Figure 1b) [Campbell, 1974; Ego et al., 1996; Winter et al., 1993]. As a consequence, thick Plio-Quaternary sedimentary basins controlled by normal faults have formed in the Gulf of Guayaquil, in particular during the past 1.8-1.6 Myr [Deniaud et al., 1999; Witt et al., 2006]. Offshore the Gulf of Guayaquil, the Grijalva Fracture Zone (GFZ), which separates the Oligocene Farallon lithosphere to the south, from the Neogene and morphologically complex Nazca lithosphere to the north, intersects the Peru trench. The trench is deepest south of this intersection and favored a $\sim 500-700 \mathrm{~m}$ accumulation of terrestrial sediment in relation with the activity of the Guayaquil canyon. There, an incipient $\sim 5 \mathrm{~km}$-wide accretionary wedge fronts the margin [Calahorrano et al., 2008; Collot et al., 2002]. North of the GFZ-trench intersection, the subduction of the Carnegie Ridge, a prominent $200-\mathrm{km}$ wide, $2-\mathrm{km}$ high volcanic ridge, uplifts the trench, which is almost bare of sediment [Lonsdale, 1978]. Subduction of the Nazca plate is also responsible for the megathrust earthquakes in1906 (Mw 8.8), 1942 (Mw7.8), 1958 (Mw7.7) and 1979 (Mw8.2), that ruptured $\sim 500 \mathrm{~km}$ of the Ecuador-Colombia plate boundary [Kelleher, 1972; Mendoza and Dewey, 1984; Swenson and Beck, 1996]. GPS data indicate a patchwork of highly coupled asperities in the rupture area of the 1906 earthquake (Figure 1b), whereas along southern Ecuador-northern Peru, inter-plate coupling is very low [Nocquet et al., 2010]. In the Gulf of Guayaquil, seismicity is low with the exception of the 1953 M7.8 earthquake that occurred offshore Tumbes (Figure 1b) and is reported in the South America SISRA catalog and by Silgado [1957]. The NE escape of the NAB superimposed on a bow effect due to the convex shape of the northern South America promontory [Bonnardot et al., 2008] are considered to release part of the inter-plate pressure, thus possibly accounting for the weak plate coupling in the Gulf of Guayaquil. Overall, such weak inter-plate coupling might facilitate subduction of incoming plate sediment.

\section{Geophysical Data and Initial Results}

[9] The 2D SIS72 data was acquired during the SISTEUR cruise on board the R/V Nadir [Collot et al., 2002]. The streamer was $4.5 \mathrm{~km}$ long with 348 groups of geophones at 12.5-m interval, recording 4-ms samples, with a 15-s record length. Source was a 48-L (2869 inch3) air gun array tuned in a single-bubble mode [Avedik, 1993] and fired at 50-m interval. The geometry yielded a 43-fold MCS data set. The line had been initially processed up to PSDM based on the Kirchhoff algorithm using the SIRIUS-2.0 software package, and a 2D Vp velocity model had been constructed by focusing analysis and iterative velocity picking [Calahorrano et al., 2008]. The resulting image (Figure 2a) shows the updip segment of the subduction channel to be a $\sim 0.8-0.9 \mathrm{~km}$-thick, $2.7-2.8 \mathrm{~km} / \mathrm{s}$ low-Vp layer dipping $\sim 4^{\circ}$ landward on average [Calahorrano et al., 2008]. The SC segment is roofed and floored by the strong and continuous Top of Subduction Channel (TSC) and Top of Oceanic Crust (TOC) reflectors that Calahorrano et al. [2008] interpreted respectively as the interplate décollement and the roof of the underthrusting oceanic crust.

\section{Methodology: 2D Fine-Scale Imaging by Integrated Iterative PSDM and Simulated Annealing Optimization}

[10] To obtain a depth migrated image and small-scale velocities, we used a two-step approach based on ray + Born waveform migration/inversion, also known as preserved amplitude pre-stack depth migration (PSDM) [Thierry et al., 1999], and very fast simulated annealing (VFSA) optimization [Ribodetti et al., 2011].

[11] 1. Iterative ray + Born waveform migration/inversion, including an iterative correction of the $\mathrm{Vp}$ velocity macromodel [Al-Yahya, 1989], is used to obtain a 2-D quantitative and accurate migrated image. Then, we computed several iterations of ray + Born waveform modeling and inversion until the convergence was achieved in order to recover the true amplitude of the velocity perturbations as accurately as possible. In case of multiple arrivals, we noticed that several iterations of single-arrival migration/inversion allowed us to estimate velocity perturbations in the areas of the model intersected by caustics as accurate as those inferred from single-iteration multiple-arrival migration [Operto et al., 2000]. Finally, the migrated image is calibrated by estimation of the reflection coefficient on the seafloor [Warner, 1990] to obtain the $\mathrm{Vp}$ velocity perturbations in the SI system.

[12] 2. An automated post-processing procedure is applied to eliminate the source signature from the migrated image, and to estimate the correct geometry (i.e., layer thickness) and the absolute values of the velocity of seismic reflectors, as well to estimate results uncertainties. The post-processing [Ribodetti et al., 2011] is formulated as an inverse problem for which the data space is composed of several vertical logs of the migrated image (namely, the limited bandwidth velocity logs). The model space is composed of the $1 \mathrm{D}$ velocity logs (namely, the impulse velocity logs), parameterized by a limited number of layers with random velocity and thickness. The relation between the data and the model is approximated by a simple time domain convolution with the limited-bandwidth source wavelet. For the post-processing, we used the wavelet obtained by linear inversion of the water wave [Ribodetti et al., 2011] based on the linear inversion method proposed by Pratt et al. [1998]. The inverse problem is solved independently for each log by a random exploration of the model space, using the VSFA algorithm [Sen and Stoffa, 1995]. The uncertainty and the error analysis (central and dispersion statistical estimators) are investigated by multiple VFSA, which allows to estimate the frequency of visits of each accepted specific cell of the model space parameterized by layer thickness and velocity [Jackson et al., 2004; Sen and Stoffa, 1995].

\section{Application to MCS Line SIS-72}

[13] Prior to apply the above processing sequence to MCS line SIS 72, we pre-processed the data to preserve phase amplitudes, using the Geovecteur software. Preprocessing included data sorting to $6.25-\mathrm{m} \mathrm{CDP}$, first pass velocity analysis, amplitudes attenuation (0.001 factor) of noisy traces, a band pass filter $(3,6,50,60 \mathrm{~Hz})$, minimum phase operator, multiple attenuation in the frequency-wave 
number (FK) domain, normal moveout velocity analysis, loose external mute, spherical divergence correction, predictive deconvolution, second multiple attenuation using Radon transform, inverse spherical divergence correction and inverse NMO correction, second band pass filter (3, 6, $50,60 \mathrm{~Hz}$ ), and sorting of CDP to shot gather. Although, the work by Calahorrano et al. [2008] provided new constrains on physical and mechanical properties at the scale of the $\mathrm{SC}$, applying our new processing sequence allows refining the spatial resolution of the $\mathrm{SC}$ velocity structure, enhancing the reflections coherency, and modeling reflectors as thin layers at the roof and floor of the subduction channel. The improvement and accuracy of the $\mathrm{Vp}$ velocity model, the migrated image and the validity of the post-processed model are presented in the auxiliary material. ${ }^{1}$ Although some reflection patterns may be 2D-migration artifacts or 3D-outof-plane effects, in the following we mostly interpret variations in reflection at a scale relative to the average thickness of the two major SC internal sequences.

\section{Results and Interpretation}

\subsection{Large-Scale Structure and Geometry}

[14] The SC varies in thickness from $630 \mathrm{~m}$ to $1150 \mathrm{~m}$, and shows a large scale, ramp-flat structure that dips $\sim 6^{\circ}$ landward (Figure 2b). The channel tapers down landward from $\sim 1000 \mathrm{~m}$ at $\mathrm{km} 67$ to less than $300 \mathrm{~m}$ at $\mathrm{km} 63$, where TSC reflector outlines a footwall ramp (Figure 2a) [Calahorrano et al., 2008]. The flat segment of the SC rises gently seaward. It is buckled and mimics the topography of the underlying TOC reflector that reveals topographic irregularities including small seamounts and horst-and-graben structures. It is remarkable that groups of up to 300-m-thick, very strong $\mathrm{SC}$ reflectors extending landward from $\mathrm{km} 83$ are associated with both the TSC and TOC reflectors (Figure $2 b$ ).

[15] In the trench, a package of subhorizontal, wellstratified turbidite is uplifted by $150 \mathrm{~m}$ and deformed by the seaward-verging frontal thrust (T0) [Calahorrano et al., 2008] thus creating the youngest thrust sheet (TS1) (Figure 3). Farther landward, our new image allows interpreting a remarkable structural continuity over the $24 \mathrm{~km}-$ long, studied segment of the SC. Continuity is followed from the landward end of the section at $\mathrm{km} 67$ and depth of $\sim 7.5 \mathrm{~km}$ (Figure 4) to the toe of the margin slope near km 89 , where continuous, well-bedded and slightly warped up internal reflectors come close to the seafloor, thus forming a long thrust sheet (TS2) (Figure 3). TS2 overthrusts TS1 along thrust fault (T1) thus forming a $150 \mathrm{~m}$-high seafloor relief.

\subsection{Evidence for Roof and Basal Décollement Thrusts}

[16] Although TSC reflector, which is strong, continuous, and sharply truncates seaward dipping reflectors at the bottom of the upper-plate basement (Figure 4), was interpreted as the décollement thrust [Calahorrano et al., 2008], the new PSDM image (Figure 3) argues against continuity between the interpreted TSC décollement and the active deformation front. Based on the structural continuity of the SC along the line, the TSC reflector can be extended

\footnotetext{
${ }^{1}$ Auxiliary materials are available in the HTML. doi:10.1029/ 2011JB008429.
}

straightforwardly up to near the seafloor at $\mathrm{km} 88, \sim 3 \mathrm{~km}$ landward of the deformation front. Accordingly, the TSC reflector and the frontal thrust $\mathrm{T} 0$ are structurally disconnected (Figure $3 b$ ). In contrast, although deep seismic reflectors are poorly continuous at $\mathrm{km} 84-85$, thrust fault $\mathrm{T} 1$ is interpreted to splay away from near the TOC reflector, and join seaward active fault $\mathrm{T} 0$, pointing to the likely structural continuity between the TOC reflector and the frontal thrust. This structural interpretation implies tectonic activity along a basal thrust zone. Hence, the SC is inferred bounded by roof and basal décollement thrusts.

\subsection{Internal Structures of the SC}

[17] Internal structures of the SC derived from the true amplitude migrated image reveal two main stratified sequences, which are discriminated from their reflector patterns. The lower sequence (Ls) is 220-500-m-thick, and becomes distinct below T0 fault, whereas the upper sequence (Us) is 450-800-m thick. Both sequences show a variable seismic pattern, which may reflect sedimentary and tectonic structures. At $\mathrm{km} \mathrm{73,} \mathrm{Ls} \mathrm{sequence} \mathrm{and} \mathrm{the} \mathrm{TOC} \mathrm{reflector} \mathrm{are}$ affected by a $\sim 250 \mathrm{~m}$ vertical offset that we interpret as a normal fault ( $\mathrm{F}$ in Figure 4) in the oceanic crust.

[18] Sequence Ls divides into three units on the basis of their reflectivity and structural pattern. Unit Ls1 is the shallowest $(5.5-5.9 \mathrm{~km}$, at $\mathrm{km} \sim 81-87)$ and underlies $\mathrm{T} 1$ thrust up to $\mathrm{km} 87$ pointing to the décollement nature of its contact with overlying Us Unit. Unit Ls1 is thinly stratified and weakly reflective. Unit Ls2 extends at depths ranging

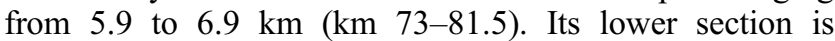
strongly reflective where it drapes an irregular segment of the oceanic crust and the hanging wall block of normal fault F. Seaward verging reverse and thrust faults, which appear to sole out near the TOC reflector, are interpreted to deform Ls2 at depths greater than $\sim 6.0 \mathrm{~km}$. Unit Ls3 lies on the footwall block of normal fault $\mathrm{F}$ at a depth of 6.9 $7.8 \mathrm{~km}$, and shows structural complexity with thickness variations, folding and seaward verging thrust faults. The contractional deformation affecting Ls unit provides additional support for the TOC reflector and likely part of Ls unit to feature a basal thrust zone.

[19] Sequence Us was divided into four units on the basis of their reflectivity, boundary types, and structural patterns. Unit Us 0 is thinly bedded and moderately reflective in both the trench and thrust sheet TS- 1 . In the SC, between $\mathrm{km} 80$ 88 , the unit varies in thickness from 180 to $400 \mathrm{~m}$ then thins toward $\mathrm{km} 79$, where the unit disappears. Its reflective pattern varies from weak, to very strong between $\mathrm{km} 79$ and 83 . At their landward termination, Us0 strata lap onto underlying unit Us1 (km 81-82) pointing to a likely stratigraphic contact. Unit Us1 extends along the SC from $\mathrm{km} 76.5$ to 89 . In its seaward half, Us1 undulates, is $250-300-\mathrm{m}$-thick, well bedded to discontinuous and poorly reflective (Figure 3). The unit reaches $580 \mathrm{~m}$ in thickness near $\mathrm{km} 79$. Between $\mathrm{km}$ $77-81$, the Us1 upper section is strongly reflective and the reflectivity extends across the boundary between units Us0 and Us1. Unit Us1 reflectors are affected by small throw vertical offsets between $\mathrm{km} \mathrm{78-84}$ suggesting either artifacts or small-scale, high-angle normal faults. Near the landward termination of Us1, the highly reflective uppermost bedding is conformable with the TSC reflector, which sharply truncates the bedding of the overlying margin wedge rocks, thus 


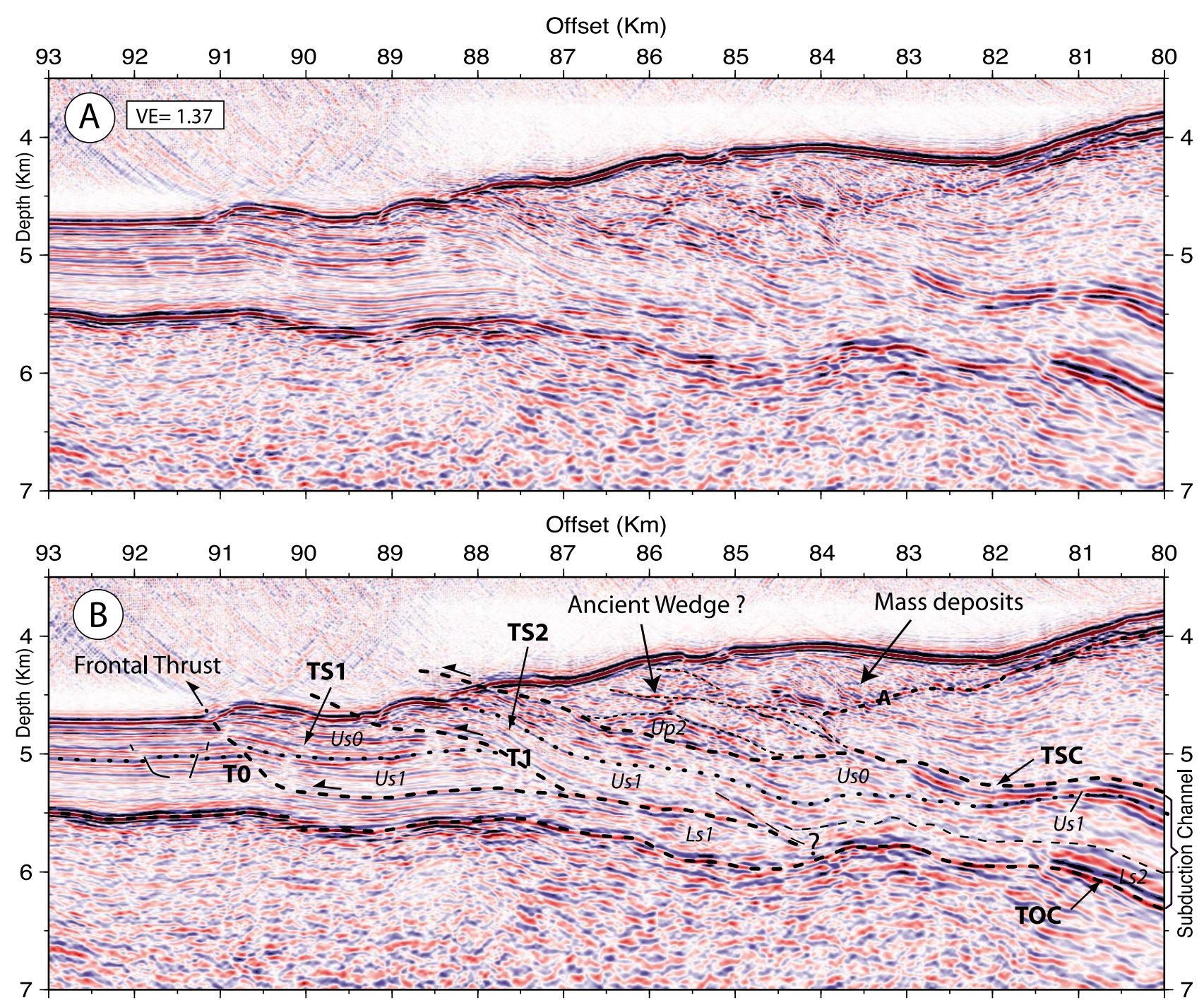

Figure 3. Close-up of the frontal part of PSDM line SIS-72. Location is shown in Figure 2. (a) Un-interpreted data, (b) line drawing; TSC and TOC as in Figure 2. Us0-Us1 = channel Upper Sequence sedimentary units. Ls1-Ls2 = channel Lower Sequence sedimentary units. TS1 = youngest thrust sheet; TS2 = long thrust sheet; $\mathrm{T} 0$ and $\mathrm{T} 1=$ thrust faults; $\mathrm{Up} 2=$ possibly underplated duplex. Note the continuity of TS2 from the seafloor at $\mathrm{km} 88$, downdip, and strongly reflective layers below TSC and above TOC reflectors.

supporting the roof thrust nature of TSC. Unit Us2 is a rhombic-shaped block that is present between $\mathrm{km} 74$ and 79, and reaches $\sim 800 \mathrm{~m}$ in thickness, near $\mathrm{km} 76$. It is well stratified, poorly reflective, and its bedding shows a sharp dip increase with respect to Us1 bedding. Us2 uppermost section has a wedge shape thinning updip possibly implying some tilting of the unit. The nature of its relationship to both Us1 and Us 3 units is however ambiguous. Us1/Us2 boundary, i.e., contact R1 could be either structural through a fault, or sedimentary via Us1 downlaps onto Us2 bedding. Us2 beds clearly downlap onto Us3 revealing the unconformable nature of contact R2. However, the boundary could either be a fault or a stratigraphic contact in as much as the possible initial boundaries of the sedimentary units were likely deformed during subduction. Were these boundaries faults, then the bedding pattern relative to the fault dip direction would suggest a minor clockwise rotation along low angle, normal faults. Unit Us3 has a sigmoid cross section or deformed rhomb section, thinning away at $\mathrm{km} 76$ and 70 , and at a depth of $\sim 6.5 \mathrm{~km}$. The interpreted reverse and thrust faults that cut across underlying unit Ls2 between $\mathrm{km} 74$ and 76 deform Us3 implying that deformation postdates Us3 deposition. The poor resolution of Us3 reflections near $\mathrm{km} 72$ precludes defining its contact nature (R3) with underlying Unit Us4. Unit Us4 together with Ls3 form the bulk of the flat segment of the SC that reaches $1150 \mathrm{~m}$ in thickness. Us4 seismic facies changes laterally from well-bedded, highly reflective to poorly reflective and chaotic. Folding and seaward-verging thrusting deforms part of Us4 conformably with sequence Ls3 indicating synchronous deformation. In conclusion, reprocessed Line SIS72 provides support for two décollement thrusts bounding a highly deformed zone. This zone experienced extensional and contractional tectonism 

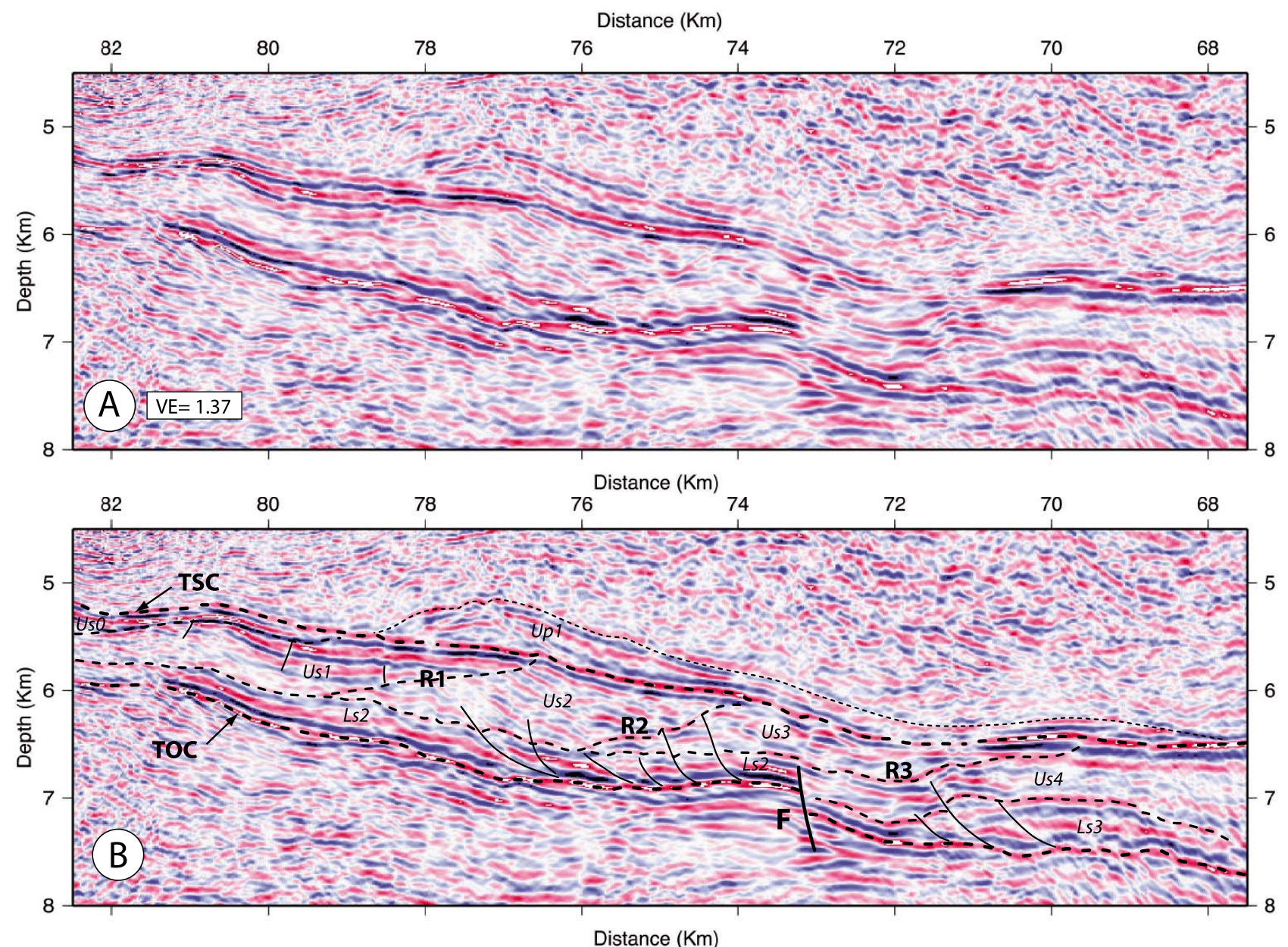

Figure 4. Close-up of the subduction channel of PSDM line SIS-72. Location is shown in Figure 2. (a) Un-interpreted data, (b) Line drawing; TOC as in Figure 2. Us0-Us4 = channel Upper Sequence sedimentary units. Ls2-Ls3 = channel Lower Sequence sedimentary units. F = normal fault; Up1 = possibly underplated duplex. R1-R3 seismic discontinuities between Us units; Note possible small scale normal faults affecting Us1 unit, and reverse, thrust faults and folding affecting Ls2-3 and Us3-4 units. Strong reflectivity is associated with layers related to TSC and TOC reflectors.

and shows that a mid-level décollement may have separated Us and Ls units.

\subsection{Lens-Shape Structures in the Over-Riding Margin}

[20] The initial PSDM image had revealed a lens-shape seismic structure that overlies reflector TSC [Calahorrano, 2005]. This puzzling structure is asymmetric, $400 \mathrm{~m}$-thick, about $6 \mathrm{~km}$-long (Up1 in Figure 4). The structure shows continuous seismic horizons of moderate amplitude, alike those of the SC, and form a fold conformable with overlying basement structures. A similar but smaller lens-shaped structure is evident near the margin front at $\mathrm{km} 86$ (Up2 in Figure 3). Up2 structure shows, however, a complex structural relationship with overlying rocks possibly forming small imbricates at the margin front. Both Up1 and Up2 structures were truncated at their base along the TSC reflector.

\subsection{A Refined Vp Velocity Model of the SC and Lowermost Margin Wedge}

[21] A refined Vp velocity model (Figure 5a) was computed by summation of the velocity macromodel (Figure S1c of the auxiliary material) and the mean broadband best fitting perturbation model (Figures $6 \mathrm{~b}$ (top), 7a (top), and 7b (top)). This velocity model illustrates a velocity inversion associated with the SC where velocities reach values as low as $2.7-3.1 \mathrm{~km} / \mathrm{s}$ in contrast with $3.2-4.0 \mathrm{~km} / \mathrm{s}$ velocities within the overlying margin rocks. Beneath the SC, velocities increase to $4.2-4.5 \mathrm{~km} / \mathrm{s}$ at the top of the oceanic crust. These findings are in agreement with the larger-scale velocity model of the SC presented by Calahorrano et al. [2008]. Their velocity model of the SC also revealed two areas of subtler, secondary Vp variations. These Vp variations appeared as well in our macro-velocity model after a migration/inversion iterative refinement (See Text S1 and Figure S1c of the auxiliary material), and were further 


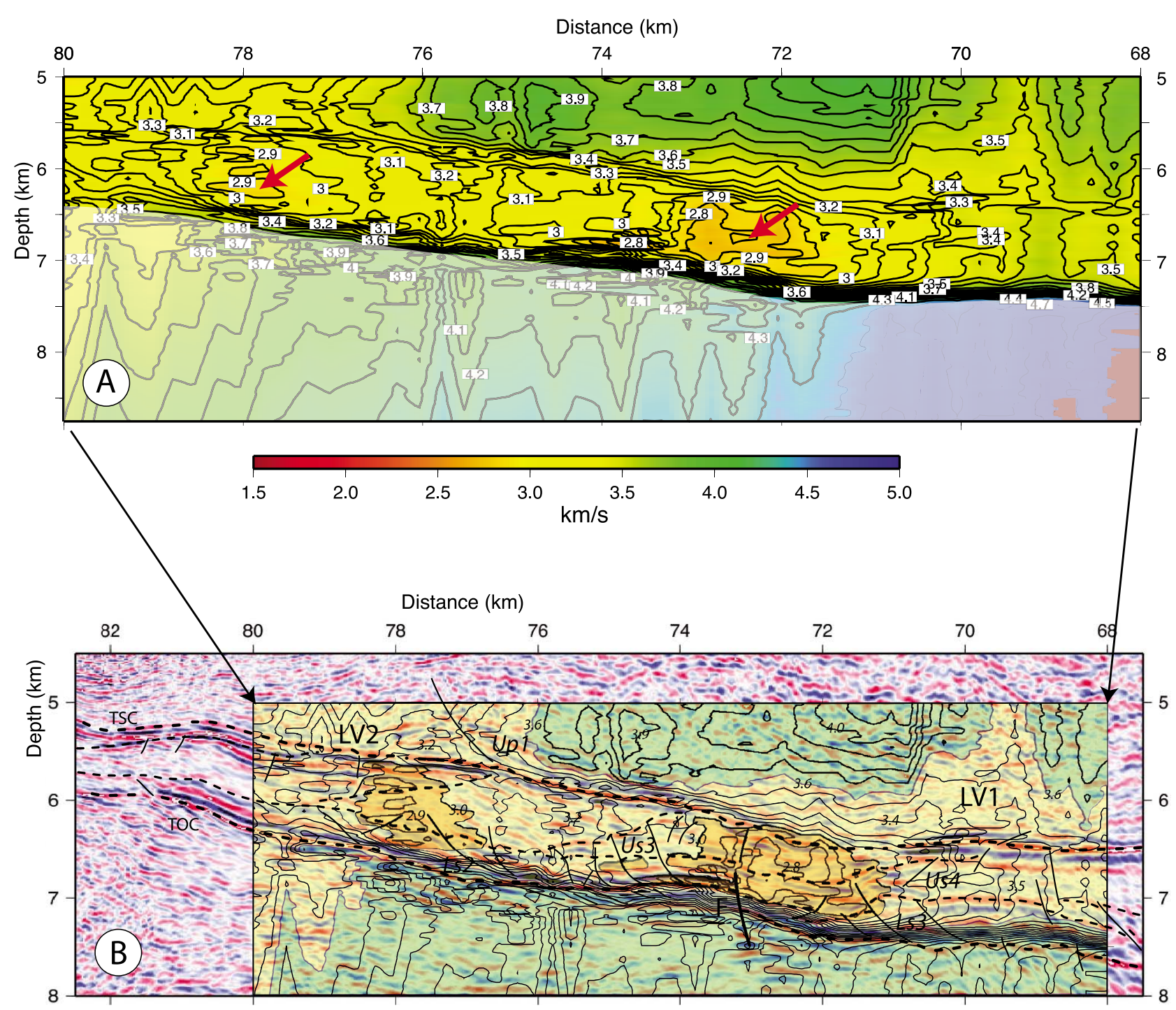

Figure 5. Fine scale Vp velocity model of the deepest segment of the subduction channel as obtained after post-processing of the migrated image. (a) Velocity contours in $\mathrm{km} / \mathrm{s}$. Note the relative low velocity of the channel; red arrows point to patches of lowest velocity; Dimmed area indicates zone with poor velocity control. (b) Superposition of the velocity model over the PSDM image of the subduction channel. Note two low velocity anomalies LV1 and LV2 in the margin wedge suggesting fluid-altered rocks or underplated material; the channel low velocity patches locate respectively at a depth of $6 \mathrm{~km}$ ahead of a seaward verging thrust zone, and at a depth of $7 \mathrm{~km}$ sandwiched between fault $\mathrm{F}$, a likely source of fluids, and compressively deformed Ls3-Us4 unit.

refined by our post-processing procedure (Figure 5a). First, two patches of remarkably low velocity, reaching 2.7 and $2.9 \mathrm{~km} / \mathrm{s}$ (Figure 5a), are located within the Us sequence at $\mathrm{km}$ $72-73$ and 78 (Figure 5b). Second, two areas of $3.2-3.5 \mathrm{~km} / \mathrm{s}$ relatively low velocity set astride a $3.6-4.0 \mathrm{~km} / \mathrm{s}$, higher velocity core in the lower section of the overlying basement (LV1, LV2 in Figure 5b). The subtle SC velocity variations in the macro-model are validated with a $\sim 4 \%$ velocity variation by the sensitivity analysis of the $\mathrm{Vp}$ model presented in Text S1 of the auxiliary material (Figures S5-S6).

\subsection{Vp Perturbations of Reflectors Associated With the Roof and Floor Thrusts}

[22] On the calibrated-migrated image with absolute velocity perturbations, sets of strong positive $(\mathrm{Pa} / \mathrm{Pb})$ and negative $(\mathrm{Na} / \mathrm{Nb})$ amplitude reflectors are associated with both the roof and the basal thrusts (Figure 6a). Pa is the most continuous positive amplitude reflector along the roof thrust, although it nearly disappears at km 71-72 (Figure 6a). Pa overlies up to three negative amplitude reflectors, $\mathrm{Na}$, $\mathrm{Na} 1$ and $\mathrm{Na} 2$, which are restricted to the shallowest well-stratified 


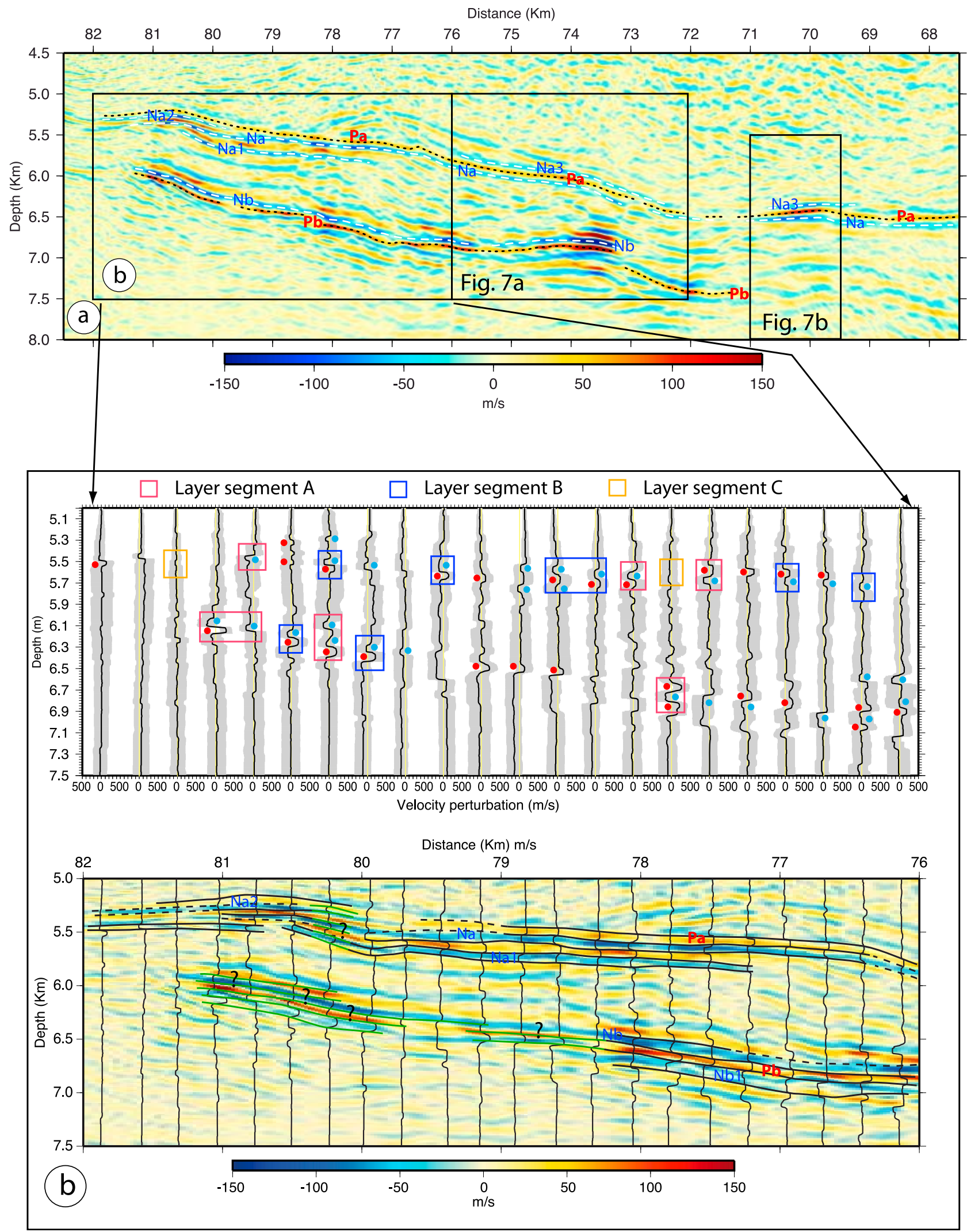

Figure 6 


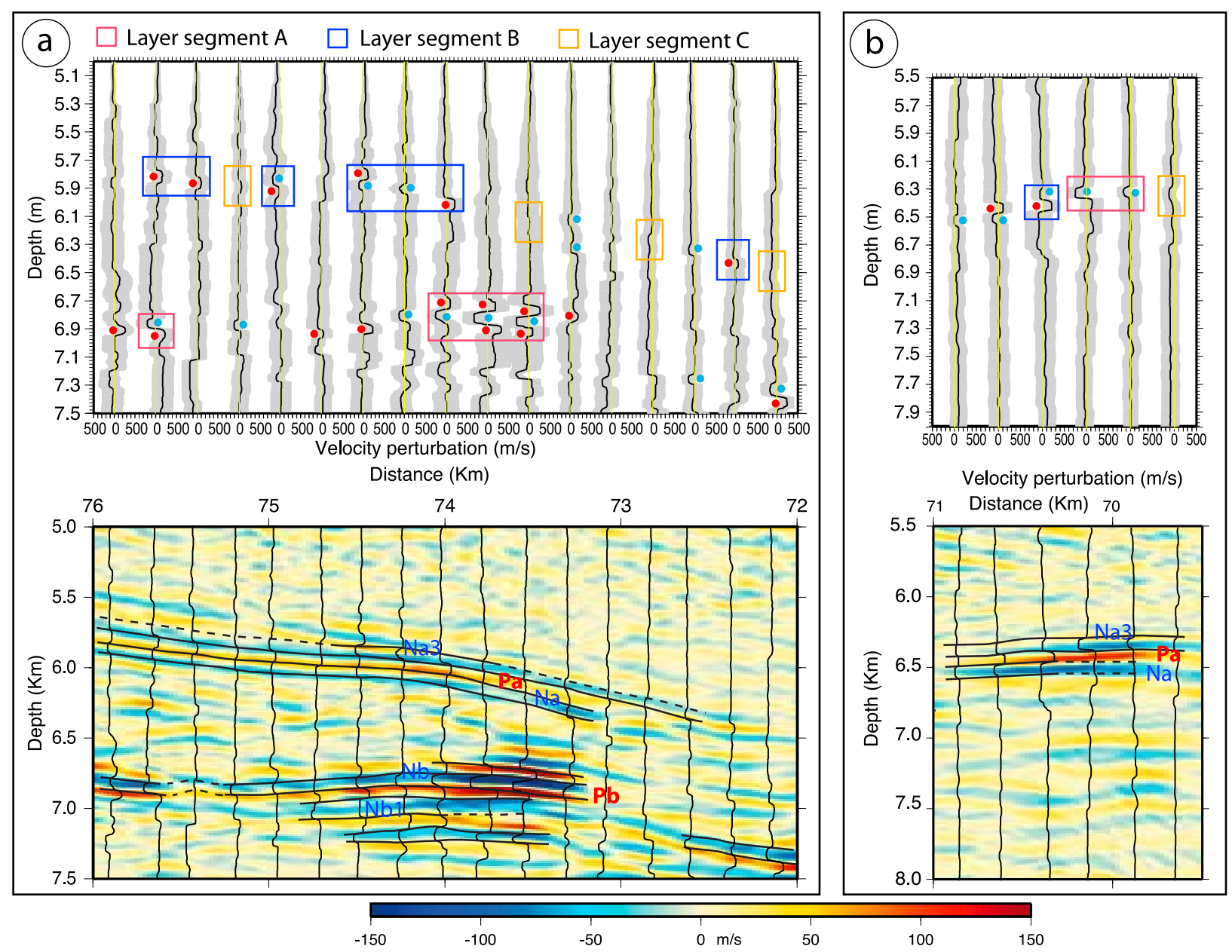

Figure 7. Results of the post-processing showing close-up of (a) middle and (b) lower segment of the channel; top panels are mean broadband perturbation models with superimposed 5-10\% standard deviation; bottom panels are mean broadband perturbation models superimposed on the depth migrated image. Captions as in Figure 6.

segment of the SC (km 77 to 81 in Figure 6a). Down dip, two negative amplitude reflectors $\mathrm{Na}$ and $\mathrm{Na} 3$ straddle reflector $\mathrm{Pa}(\mathrm{km}$ 68-76 in Figure 6a). Reflector $\mathrm{Pb}$ at the base of the SC shows very strong positive amplitude of the velocity perturbation (km 80-81, 78, 73.5-74) associated with strongly negative amplitude reflector $\mathrm{Nb}$.

[23] The reflector signatures translate into significant velocity perturbations and thickness variations in the $1 \mathrm{D}-$ velocity logs that were obtained after post-processing every $250 \mathrm{~m}$ along the line (Figures $6 \mathrm{~b}$ (top), $7 \mathrm{a}$ (top) and $7 \mathrm{~b}$ (top)). The thinnest layer to be resolved by the post-processing is however no less than the one-quarter wavelength of the seismic source, where the wavelength is the media velocity divided by the source wavelet frequency. Because the source frequency is $18 \mathrm{~Hz}$ and the average media velocity in the $\mathrm{SC}$ is $3 \mathrm{~km} / \mathrm{s}$, layers less than $42 \mathrm{~m}$-thick will not be resolved. $\mathrm{Pa}$ reflector is resolved by a 50 to $110 \mathrm{~m}$-thick layer with a 50 to $200 \mathrm{~m} / \mathrm{s}$ positive velocity perturbation, whereas reflectors $\mathrm{Na}$, $\mathrm{Na} 1$ and $\mathrm{Na} 2$ fit with $\sim 40$ to $80 \mathrm{~m}$-thick layers with $\sim 50$ to $280 \mathrm{~m} / \mathrm{s}$ negative velocity perturbations. The $\mathrm{Pb}$ reflector is resolved by a $60-100 \mathrm{~m}$ thick up to $300 \mathrm{~m} / \mathrm{s}$ positive velocity

Figure 6. Results of the post-processing applied to the deepest segment of the SC. (a) Ray + Born depth migrated image of the SC showing absolute velocity perturbations $(\mathrm{m} / \mathrm{s}) . \mathrm{Na}$ and $\mathrm{Nb}$ are negative velocity layers; $\mathrm{Pa}$ and $\mathrm{Pb}$ are positive velocity layers. (b) Close-up of upper SC segment: (top) Mean broadband perturbation models with superimposed 5-10\% standard deviation. Blue/Red dots are remarkable negative/positive velocity layers. Layer segments A, B and C are explained in the text; (bottom) Mean broadband perturbation models superimposed on the depth migrated image. In some areas as near km 80-80.5, when the modeled layers are either slightly dipping or too thin, the post-processing struggles finding the best model. A succession of thin layers with alternating high and low velocity was found however to match the data at km 80-80.5, but the calculated sequence is too deep by $\sim 50 \mathrm{~m}$. Because the post-processing is based on a layer stripping approach [Ribodetti et al., 2011], the vertical shift, which affects successively deeper layers down to the base of the channel, probably increases due to a stretching effect. 
perturbations, when $\mathrm{Nb}$ reflector reaches the highest negative velocity perturbations $>350 \mathrm{~m} / \mathrm{s}$ near $\mathrm{km} 74$ (Figure 7a).

[24] According to [Ribodetti et al., 2011] three types of layer segments can be identified on the basis of their velocity perturbations. A-layer segments have strong negative velocity perturbation $(>150 \mathrm{~m} / \mathrm{s})$. Examples are given for $\mathrm{Nb}$ at $\mathrm{km} \mathrm{73.5-74,} \mathrm{75.75} \mathrm{in} \mathrm{Figure} \mathrm{7a,} \mathrm{and} \mathrm{km} 80.75-81$ in Figure 6b; $\mathrm{Na}$ at $\mathrm{km} \mathrm{77.5,} 78$ and $\mathrm{Nal}$ at $\mathrm{km} 80.75$ (Figure 6b); and $\mathrm{Na} 3$ at $\mathrm{km} 70$ (Figure $7 \mathrm{~b}$ ). These segments are frequently overlain or rest above a high velocity layer. B-layer segments show smaller $(<150 \mathrm{~m} / \mathrm{s})$ negative velocity perturbation. $\mathrm{Na}$ examples are shown at $\mathrm{km} \mathrm{76.5;} \mathrm{78.25-78.5} \mathrm{in}$ Figure 6b). A high velocity layer locally underlies these segments. $\mathrm{Na}$ examples are given at $\mathrm{km} 70.4$ (Figure $7 \mathrm{~b}$ ) and $\mathrm{km} 75$ (Figure 7a). C-layer segments are not associated with detectable amplitude variations and therefore do not show noticeable velocity perturbations. Na examples are shown at $\mathrm{km}$ 72.25; 73.5; 75.25 (Figure 7a) and km 81.25 (Figure 6b).

\section{Discussion}

[25] The new constraints put on the sedimentary and tectonic structures of the updip segment of the SC along line SIS72 permit interpretation of the tectonic evolution over the last $\sim 450 \mathrm{kyr}$, and provide a novel insight over the mechanisms that controlled its structural fabric and fluid flows.

\subsection{Time Frame for Trench Sedimentation and SC Tectonics}

[26] Our interpretation of line SIS72 suggests that as trench sedimentation continued and subduction proceeds, sediment kept underthrusting the margin as a long sheet (TS-2) prior to initiating frontal accretion (TS-1). The roof thrust is not viewed as an out-of-sequence fault because, in contrast with T0 and T1 thrusts, no seafloor relief is associated with it (Figure 3). We then consider that the roof thrust was abandoned when T1 thrust initiated. The timing of this tectonic change can be appraised by restoring the fault-related deformation in the first $4 \mathrm{~km}$ of the wedge tip. In addition, an age line can be constructed along the roof thrust to help constrain the temporal evolution of SC tectonic deformation.

[27] Cumulated tectonic shortening along T0 and T1 thrusts is estimated to range between $2.3 \mathrm{~km}$ and $2.9 \mathrm{~km}$ taking into account a $10 \%$ error on fault finite displacements. We added diffuse tectonic shortening of the deformed sedimentary section with values ranging between 10\% [Adam et al., 2004] and a 50\% upper bound, considering that strain distribution along the SC is poorly known. Under these considerations, a simple timing reconstruction based on a constant $5.8 \mathrm{~cm} / \mathrm{yr}$ plate convergence rate [Kendrick et al., 2003] indicates that fault $\mathrm{T} 1$ initiated $46 \pm 4$ kyr to $63 \pm$ 6 kyr ago, thus implicitly dating the roof thrust abandonment at $54 \pm 13 \mathrm{kyr}$. Accordingly, this age also dates the last and youngest Us0 sediment to have underthrust the margin tip at $\mathrm{km} \mathrm{88}$. Therefore, the youngest age of both Us0 at the land-

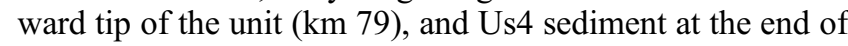
the line segment $(\mathrm{km} \mathrm{68)}$ could be roughly estimated. By considering that underthrusting of long sheet TS-2 was steady state, we added an up to $20 \%$ diffuse tectonic shortening to the estimated minimum $(8.3 \mathrm{~km})$ and maximum $(9.1 \mathrm{~km})$ lengths of TS2 between $\mathrm{km} 88$ and 79. As a result, the time required to underthrust TS-2 from $\mathrm{km} 88$ to $\mathrm{km} \sim 79$ was estimated $180 \pm 9 \mathrm{kyr}$. Hence, Us0 youngest sediment at km 79 would be $234 \pm 22$ kyr old (Figure 8). Similarly, Us4 sediment near km 68 would include $\sim 450$ kyr-old material. This approximate ages line points to an apparent change in trench sedimentation at $234 \pm 22 \mathrm{kyr}$. Prior to this age, thick packets of sediment may have filled the trench, whereas ensuing Us0 sedimentation progressively overlaid Us1 unconformably.

\subsection{Is the SC Structure a $\sim 450$ kyr Time Window on Trench Sedimentation?}

[28] Conceptually, the sedimentary architecture of the SC should reflect the lithologic changes and sedimentary dynamics that prevail in the trench as subduction proceeds. Along line SIS-72 the Nazca plate is of Oligocene age [Lonsdale, 2005] i.e., older and deeper than the southern flank of the Carnegie Ridge, where ODP Site 1238 recovered the complete Neogene sequence down to the Miocene oceanic crust [Mix et al., 2003]. Extrapolating the lithologies from this site suggests however that sequence Ls, which blankets the oceanic crust in the south Ecuador trench, consists of diatom and nannofossil ooze with discrete ash layers. The lithologies of the well-stratified reflective trench fill (sequences Us) can be approximated by fine grain turbidites and mud clasts flows inter bedded with mud and hemipelagic silty clays in accordance with sediment cored from the nearby central Ecuador trench [Lonsdale, 1978; Ratzov et al., 2010].

[29] Considering steady sediment subduction in a nonaccretionary regime, architectural variations of the trench sediment might be preserved along the SC as a function of the sediment progressive aging along the roof thrust. Preserved characteristics, among which apparent unconformities between the sedimentary units, (Figure 4) might unveil remnants of the original sedimentary architecture. For example, several turbidite and debris flow systems could have successively formed in the trench over the $\sim 234$ to 450 kyr time period, thus possibly accounting for the apparent unconformities and changes in layering dip between Us1-Us4 units. However, the 13 to $18^{\circ}$ dip angle between the apparent unconformities and the roof thrust appears too large to be of stratigraphic origin, in comparison with the shallow $0.5-2^{\circ}$ seaward dip of the trench seafloor at the Astoria and Esmeraldas deep sea fans [Nelson, 1983; Collot et al., 2008]. Then, the hypothesis of several diachronic turbidite systems is unlikely to account for the SC internal structure. Alternatively, large blocks transported with debris avalanches [e.g., Collot et al., 2001; McAdoo et al., 2000] could have contributed to the sedimentary architecture of the SC. The landward-tilted section of the $\sim 800 \mathrm{~m}$ thick Us2 unit that rests unconformably against Us3 could suggest that a $\sim 5 \mathrm{~km}$-wide coherent block of sediment slid into the trench. Nevertheless, slump blocks are expected to be more compact than surrounding trench sediment implying locally higher $\mathrm{Vp}$. Our detailed velocity model of the SC (Figure 5) does not reveal high-velocity patches within the $\mathrm{SC}$, thus discarding this hypothesis. In conclusion, the structural changes imaged in the SC are rather a consequence of tectonic deformation than the preserved signature of temporal variations of the trench sedimentary architecture. 


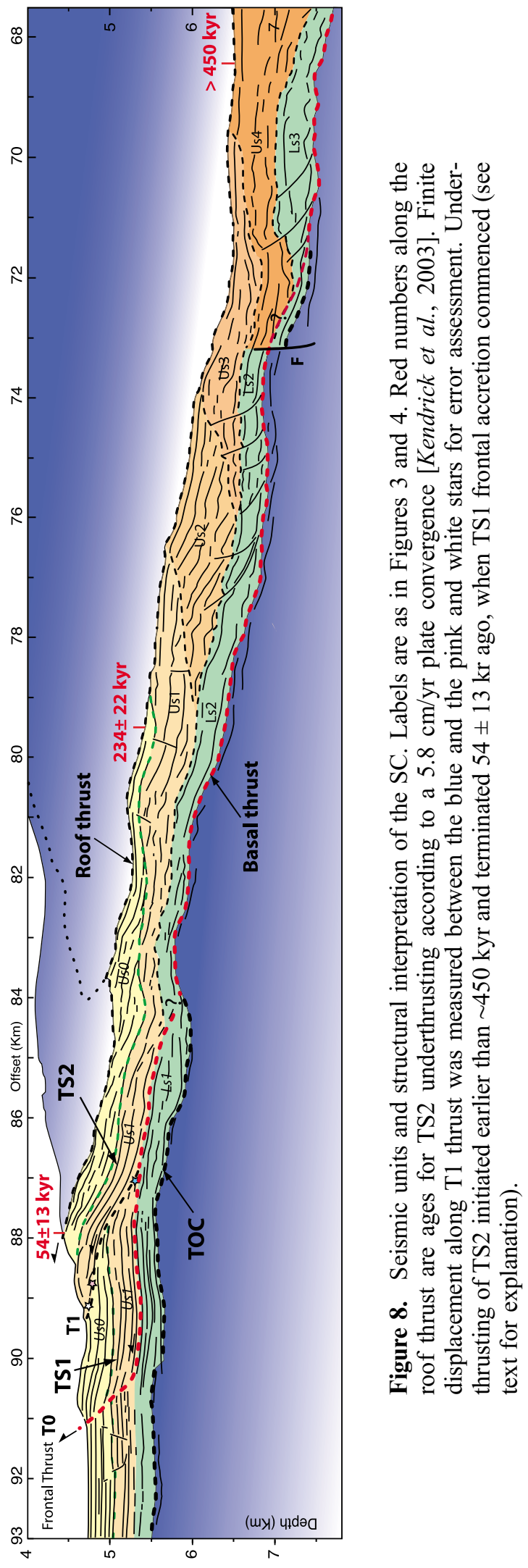




\subsection{The SC Structure: A $\sim 450$ kyr Record of Interplate Strain}

[30] A remarkable result of this study is to show that the entire $\sim<1 \mathrm{~km}$-thick sediment pile of the Nazca plate was underthrust over a distance $>23-\mathrm{km}$ during a $\sim 400$ kyr period, prior to initiating frontal tectonic accretion $54 \pm 13 \mathrm{kyr}$ ago. During these events, a specific shear fabric was acquired under increasing strain.

\subsubsection{The SC Internal Deformation}

[31] According to Shreve and Cloos [1986] tectonic deformation along the SC may reflect viscous shear as material flows downward. On the long-term, the flow of SC material can be broken up into a steady state Poiseuille flow and a Couette flow [England and Holland, 1979] (Figure 9a). Under the effect of the Poiseuille flow, sediment tend to flow seaward i.e., counter-subduction as the low-density viscous flow is driven by the downdip increasing pressure gradient exerted by the hanging wall on the channel. Under the Couette flow effect, shear develops within the SC material because subduction forces the flow downdip as material viscosity makes it stick to the SC boundaries. The resulting composite deformation (Figure 9a) suggests that a mid-level shear zone could theoretically form, depending on subduction velocity and viscosity of the media. Observations of exhumed SC and accretionary wedges that were buried at depths $<7 \mathrm{~km}$ [Moore et al., 2007; Vannucchi et al., 2008] reveal, however that their rocks mainly deformed in the brittle field, under $50^{\circ}-150^{\circ} \mathrm{C}$ temperatures.

[32] Along line SIS-72, the few discrete high-angle, small-throw normal faults that are interpreted to cut the uppermost SC layers at a depth of 5.2-5.5 km reflect both compaction and extensional brittle deformation. Such an extension regime was documented in the $500 \mathrm{~m}$-thick fossil $\mathrm{SC}$ of a former erosive margin preserved in the Northern Apennines of Italy [Vannucchi et al., 2008]. This study reported evidence for pervasive extensional shear fractures and gently dipping normal faults affecting yet poorly consolidated sediment in the shallow part $(<\sim 3 \mathrm{~km})$ of the SC.

[33] Interpreted thrust and reverse faults indicate that contractional strain becomes distributed across both Ls and Us units in the downdip part of the SC at a depth of $\sim 6.5-$ $7.5 \mathrm{~km}$, supporting a complex and highly deformed zone. This contraction contributes to thicken the SC. Near oceanic crust fault $\mathrm{F}$, thrusting distributes broadly within units Ls23 and Us3-4, with the exception of a limited area on the down throw side of fault $\mathrm{F}$, which could form a shadow zone to deformation (Figure 9e). The fault likely renders the basal thrust inactive immediately ahead of the fault. It is worth noting that contraction begins penetrating deeply into

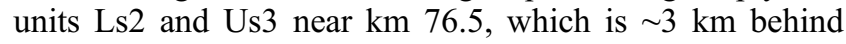
fault $\mathrm{F}$ location. Considering that the basal thrust is active at the average plate convergence rate, Fault $F$ traveled this distance perhaps over the last $\sim 50 \mathrm{kyr}$, an age that is close to our estimated age for basal thrust inception. Motion transfer across fault $F$ was then either accommodated by a ramp fault connected to the basal thrust near $\mathrm{km} 71$, or distributed across the greater part of the SC further landward (Figure 9e). This analysis brings to light the driving influence of a subducting oceanic fault scarp on the shear distribution in the SC.

[34] The gently seaward-dipping contacts R1 to R3 between units Us1-Us2, Us2-Us3 and Us3-Us4 are geo- metrically compatible with en echelon faults that formed during simple shear deformation. Us2 and Us3 units likely acquired their rhomb like shape during this tectonic shearing. The interpreted en echelon faults formed in a similar manner as synthetic Riedel shears in a strike-slip environment, according to the scheme by [Logan et al., 1992]. Therefore, the sense of slip along faults R1 to R3 owes to be normal, an inference that is compatible with our structural interpretation of line SIS-72. Synthetic R shears form at a $\sim 15^{\circ}$ angle relative to the main line of faulting and they further achieve a closer angle as shearing along the main fault proceeds [Davis and Reynolds, 1996]. Accordingly, the $\sim 13^{\circ} \pm 1^{\circ}$ angle of fault $\mathrm{R} 1$ to the roof thrust is in good agreement with a mature roof thrust (Figure 9e). Although limited, the vertical displacement of R1 to R3 low-angle normal faults implies motion along the roof of unit Ls, which is thus interpreted as a mid-level décollement. The décollement may have formed along the Us/Ls boundary, which separates the interpreted sandy to hemipelagic trench fill from an underlying pelagic unit. This décollement level is substantiated by thrust fault $\mathrm{T} 1$, which presumably soled out on Us1/Ls1 boundary (Figure 3). Faults R2 and R3 were later deformed by folding and thrust faulting associated with the downdip increasing strain. Similarly, in the exhumed SC of the Northern Apennines, Vannucchi et al. [2008] document discrete normal faults, which become overprinted by contraction in the SC deeper part $(>5 \mathrm{~km})$. In contrast with normal faulting, Riedel shears and thrust faults hardly ever form in the down going plate and trench sediment, hence indicating that SC Riedel shear and contractional strain was acquired during subduction. An important implication of the contractional strain identified within the $\mathrm{SC}$ is that, a few $\mathrm{km}$ downdip from the margin tip, tectonic pressure $\left(\mathrm{P}_{\text {tec }}\right)$ (maximum horizontal principal stress) cannot be neglected when calculating the total pressure $\left(\mathrm{P}_{\mathrm{t}}\right)$ supported by the $\mathrm{SC}$ because $P_{t}$ equals the lithostatic pressure $\left(P_{\text {lit }}\right)$ augmented by $P_{\text {tec. }}$

[35] In conclusion, our structural interpretation of line SIS-72 does not provide evidence for Poiseuille flow within the studied portion of the SC, but strongly supports brittle and slip behavior within a mega-shear zone. This behavior requires the rheology to vary from elastic to plastic depending on material strength, temperature, stresses and shear rates, and fluid pressure.

[36] SC excess pore pressure, is shown to reach up to $\sim 40 \mathrm{MPa}, 25 \mathrm{~km}$ from the trench [Calahorrano et al., 2008], a value that is close to the $32 \mathrm{MPa}$ calculated $20 \mathrm{~km}$ from the trench in the Nankai SC [Tobin and Saffer, 2009]. This elevated pore pressure considerably weakens SC material and facilitates internal deformation. According to the Vp-Porosity empirical relationship by Erickson and Jarrard [1998], the two patches of remarkably low velocity identified within the SC (Figure 5) are interpreted as zones of slightly higher porosities, and hence higher fluid content, that were preserved within an otherwise more compacted or finer grain sediment. Although sediment permeability and compaction by loading are key parameters for fluid flow, faulting squeezes sediment and concurrently affects porosity and fluid flow [Knipe, 1993]. Interestingly, the low velocity patches are located up dip of thrusting zones (Figure 9e) from which, fluids were potentially expelled to accumulate in the interpreted fluid sinks. Alternatively, the deepest fluid sink is associated with 

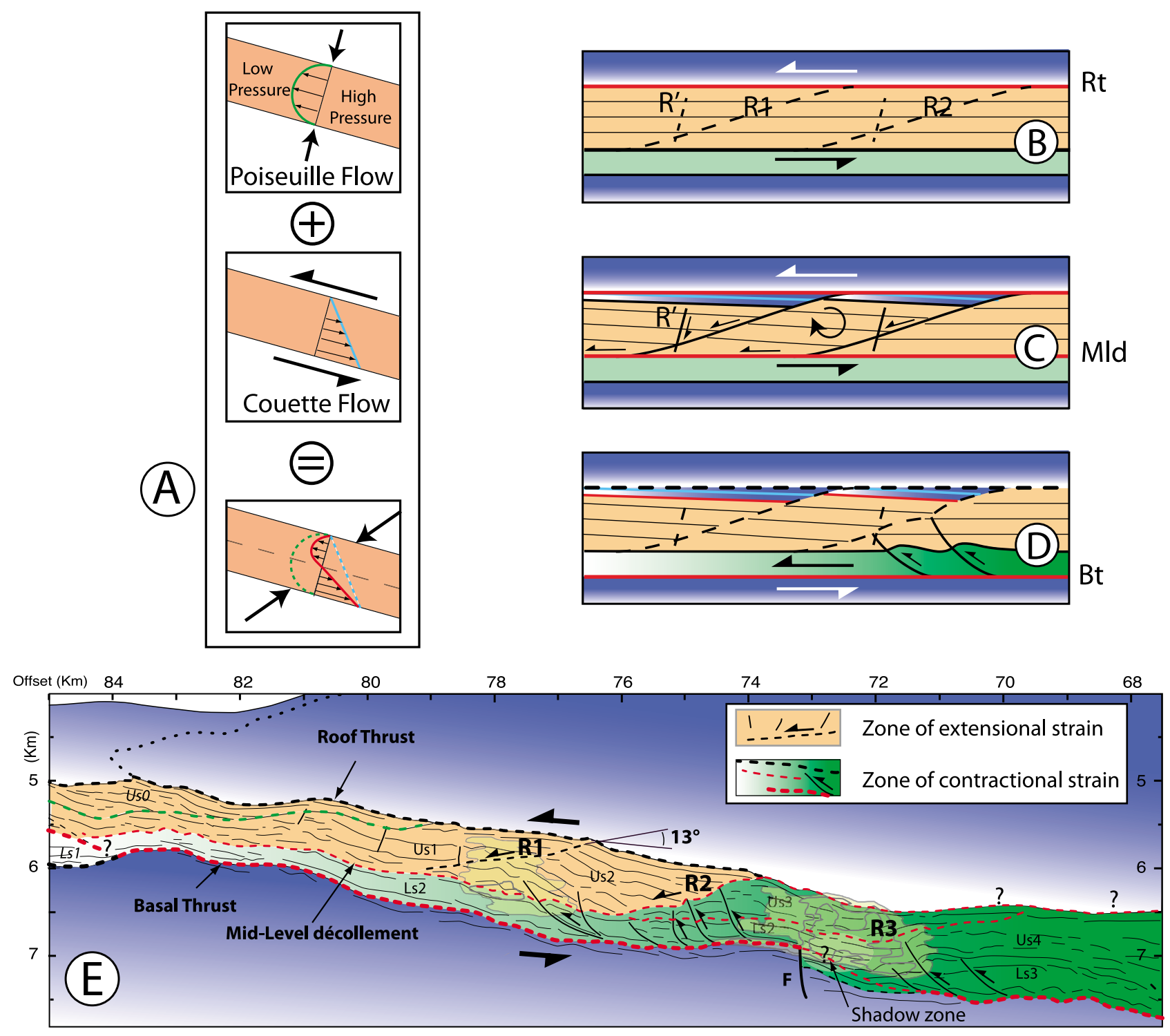

Figure 9. Deformation pattern in the SC. (a) A homogeneous viscous flow in the SC is theoretically driven by Poiseuille flow due to the pressure gradient exerted on the channel by the hanging wall (as a result, weak material tends to flow counter-subduction) and Couette flow due to subduction drag forces that shear material downdip [England and Holland, 1979]. The resulting viscous flow is the red curve. (b) Considered as a mega-shear zone, the SC develop conjugate fault arrays with synthetic (R) and antithetic (R') Riedel shears; $\mathrm{R}$ shear form as faults with a normal component from the roof thrust ( $\mathrm{Rt}$ ) at an acute angle of $\sim 15^{\circ}$ to the shear direction, and sole out on a mid-level décollement (Mld). (c) R shear activation and block rotation tend to trap thin layers of the overlying margin rocks that are subsequently captured by the SC during activation of the roof thrust. This process promotes basal erosion, upward migration of the roof thrust and thickening of the channel. (d) When the roof thrust is abandoned and the basal thrust (Bt) activated, SC units deform under contraction together with R shear. (e) Strain pattern interpretation in the SC along line SIS-72. Down to a depth of $6.5 \mathrm{~km}$, upper stratigraphic unit Us is dominantly affected by small normal faulting and large $\mathrm{R}$ shear faults, whereas lower unit Ls progressively accommodates more contractional strain. Downdip from a depth of $\sim 6.5 \mathrm{~km}$, contraction intensifies, folds form and thrust faults tend to distribute across both Us and Ls units, forming a highly deformed zone in green. This zone may transfer part of the plate convergence from the updip basal thrust (left of F) to the downdip section of the SC or basal thrust (right of shadow zone) via a ramp thrust or distributed deformation. Superimposed contours represent areas of lowest Vp velocity (see Figure 5). 
Fault F, which might be regarded as a conduit for fluids released from the underlying oceanic crust and mantle during dehydration processes [Ranero et al., 2003].

\subsubsection{The Roof Thrust: An Abandoned Megathrust} Acting as a Permeability Barrier?

[37] The continuity of the roof thrust along line SIS-72 supports a weak, mature fault zone that has accommodated substantial amount of displacements during complete underthrusting of a long sheet of sediment. Total sediment underthrusting requires maintaining a low-friction at the interplate décollement, a process that is related to the fluid content and physical properties of trench sediment [Hubbert and Rubey, 1959; Le Pichon et al., 1993; Saffer et al., 2000; Tobin et al., 2001]. The low friction owes to an elevated pore fluid pressure that results from the rapid tectonic burial in the SC of high-porosity, low-permeability, fluid-rich surface trench sediment [Le Pichon et al., 1993; Sage et al., 2006]. Consequently, underthrust sub-surface sediment remain under-consolidated relative to overlying wedge rocks [Saffer, 2003] thus favoring the propagation of the décollement. Structurally, at the margin front the décollement zone is a $\sim 9-40 \mathrm{~m}$ thick shear zone that comprises a low permeability, ductile fault core or gouge overlying undeformed fluid-rich sediment [Tobin et al., 2001; Maltman and Vannucchi, 2004]. A highly fractured, high-permeability damaged zone overlies the fault core [Caine et al., 1996; Saffer, 2003], and forms together with weakly fractured margin rocks, a localized hydraulic conduit [Tobin et al., 2001; Maltman and Vannucchi, 2004; Moore, 1989] along which, fluids flow under pressure fluctuation in relation with cyclic stress conditions [Morgan and Karig, 1995; Ujiie et al., 2003]. Cross-fault fluid flow is retarded across the ductile part of the fault, perhaps because of aligned clay minerals, so that fluid overpressure can build up as down going sediment is rapidly overloaded by the advancing margin wedge [Tobin et al., 2001; Sage et al., 2006].

[38] Our structural interpretation of line SIS-72 suggests however, that the roof thrust was abandoned, thus raising the question of its present role as a long-term conduit or a barrier for fluid flow. The 8 to $40 \mathrm{MPa}$ excess pore pressure calculated within the SC [Calahorrano et al., 2008] together with its low-velocity patches and the brightest reflectors associated with the roof thrust, support that fluids are trapped in the SC. Layer segments A and B-type, i.e., layers modeled with strong to moderate negative velocity perturbation (Figures 6 and 7) are inferred to reflect porosity variations in fluid-rich sediment layers potentially characterized by excess pore pressure. Accordingly, over-pressured fluids would characterize the uppermost SC stratigraphic layers associated with modeled layers $\mathrm{Na}$ to $\mathrm{Na} 2$ (Figure 6b). The model of fluid flow by Saffer et al. [2000] indicates that lateral fluid flow is possible in the SC if intrinsic sediment permeability is strongly anisotropic or if flow is focused along permeable layers. Moreover vertical fluid flow requires densely spaced, high-permeability conduits. We believe that tectonic deformation within the channel has created the conditions for some fluid to migrate upward and accumulate not only in mid-level reservoirs, but also in the uppermost stratigraphic layers of the SC.

[39] Layer segments C-type, such as Na layer at km 7172 , do not show a velocity contrast with overlying rocks implying that $\mathrm{Na}$ layers are fluid-depleted, possibly because they are hydro geologically isolated from main fluid-rich layers [Ribodetti et al., 2011]. According to Ranero et al. [2008], when the décollement is active at erosive margins, most fluids are inferred to drain from the plate boundary through the fractured upper plate to seep at the seafloor. Hence, the fluid-depleted state at layer segments C-type suggests that, when the roof thrust was active, fluids migrated from the $\mathrm{SC}$ and heterogeneously invaded overlying margin rocks, as supported by their relatively low velocity (Lv1 in Figure 5b). In conclusion, we interpret the inactive roof thrust as an overall permeability barrier for SC fluids that remain dominantly trapped in the upper most stratigraphic layers of the SC. Based on microstructural observations of the décollement zone in Nankai [Ujiie et al., 2003], we speculate that after shearing died along the roof thrust, pore spaced collapsed and cementation formed binding brecciated fragments to create the thin, relative $50-100 \mathrm{~m} / \mathrm{s}$ high velocity modeled layer $\mathrm{Pa}$ that fits TSC reflector (Figure 6). Consequently, when cementation is no longer destroyed by cyclic stress conditions, the fault core, and possibly its associated damage zone act as a barrier for fluid flow.

\subsubsection{A Possible Mechanism for Basal Erosion}

[40] The development of Riedel shear faults across the SC may have an implication for a different form of the basal erosion proposed by von Huene et al. [2004]. These authors suggested that along a weak plate boundary zone, high-pore pressure hydrofractured the underside of the margin basement, dislodging clasts that subducted. In our hypothesis, shearing could fully cut up into the overlying margin wedge rocks so that fluids migrate preferentially along the newly created shear zone. This process could be facilitated by the formation of $\mathrm{R}$ faults oblique to the SC (Figures 9b-9d). In this model, a wedge space opens below the roof thrust as a result of the small rotation of the Us unit along the $\mathrm{R}$ faults. Due to lithostatic pressure, overlying margin rocks subside and fill up the wedge space. Subsequent re-activation of the roof thrust will capture the subsided rock layers, which end up being incorporated to the SC. This process could promote basal erosion as well as upward migration of the roof thrust and thickening of the SC. In this hypothesis, the wedgeshaped uppermost Us2 layers (Figure 4) may be viewed as enclosing slivers of damage margin rocks.

\subsubsection{Underplating and Basement Damage Processes Associated With the Roof Thrust}

[41] The remarkable lens-shaped structure Up1 and a heterogeneous, low-Vp velocity zone (Figure 5b) characterize the bottom of the upper plate. The similar seismic facies between Up1 and the SC, and the slightly higher Up1 velocity (Figure 5, 3.2-3.6 km/s versus $2.9-3.2 \mathrm{~km} / \mathrm{s}$ ) suggest that Up1 originated from dewatered subducting sediment, and is therefore interpreted as an underplated duplex. The iso-velocity contours of the low velocity zone mimic the roof thrust geometry, in particular between km 69 and 74 along the line, supporting that the low velocities were acquired during subduction. Therefore, this low Vp velocity zone calls either to under plated sediment less well imaged than Up1 or to fluid-rock interaction in a damage zone (LV1 in Figure 5).

\subsubsection{The Basal Thrust Zone: A Recently Activated Mega-Shear}

[42] The $\sim 3-\mathrm{km}$ finite displacement accumulated along T0 and T1 thrust faults requires an equivalent amount of 

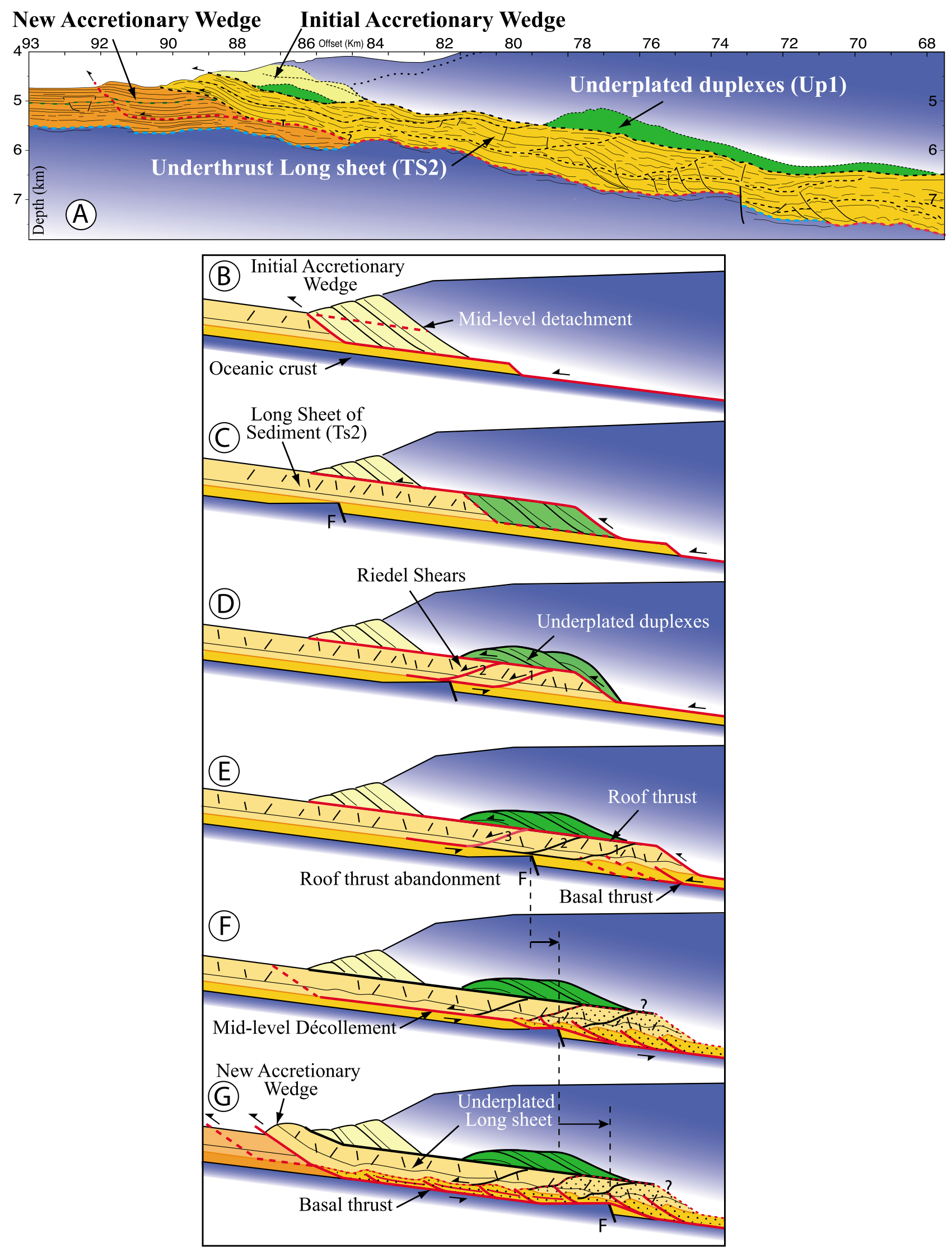

Figure 10 
displacement to be taken up by basal shearing along the SC. Seismic imaging suggests that compressive strain essentially localizes near the TOC with evidence for discrete shortening within Ls sequence downdip from a depth of $\sim 6.5 \mathrm{~km}$ along the SC (Figures 4 and 8). The remarkable low-velocity perturbations modeled along layer $\mathrm{Nb}$ and other layers below $\mathrm{Nb}$, in particular at $\mathrm{km} \mathrm{73-74} \mathrm{(Figure} \mathrm{7),} \mathrm{77-78} \mathrm{and}$ 80-81 (Figure 6), support that shearing distributes within weak, high-porosity, fluid rich layers of unit Ls and possibly fractured rocks of the uppermost section of the oceanic crust (Figure 9e). Hence, although shear had to localize once at the Us/Ls boundary to account for the growth of the Riedel shears, and the initiation of $\mathrm{T} 1$ thrust fault (Figure 3), deformation later stepped down and localized near the TOC, affecting sequence Ls. Fluid concentration near the base of the SC is substantiated by drilling results of Costa Rica ODP-Leg 170 [Kimura et al., 1997], and results of NewHebrides ODP-Leg134 [Collot et al., 1992] support basal shearing. Consolidation tests conducted on Leg 170 cores indicate that sediment near the base of the SC remains essentially undrained and show pore pressure in excess of 3.1 MPa [Saffer et al., 2000]. Drilling the subduction zone between the North d'Entrecasteaux Ridge and the New Hebrides Island arc revealed that weathered, volcanic breccias of the ridge basement [Coltorti et al., 1994] was sheared off and incorporated as 10 to $>60 \mathrm{~m}$-thick tectonic slivers into the accretionary wedge [Pelletier and Meschede, 1994]. This result demonstrates that the décollement can peel off thin sections of altered volcanic basement that are underplated.

\subsubsection{What Caused the Shift From the Roof to the Basal Thrust?}

[43] Scaled sand box experiments have shown that under high basal friction at the base of the subducting sediment unit, the growth of accretionary wedges display cycles alternating between frontal imbricate thrusting and underthrusting of long, poorly deformed sheets [Gutscher et al., 1996]. Underthrusting of a long sheet is made possible when less energy is required to sustain motion along the roof thrust than to initiate a new basal thrust. According to the mechanical analysis by [Gutscher et al., 1998], this condition is fulfilled when 1) basal friction is high (i.e., $83 \%$ of the internal friction), 2) surface slope is shallow i.e., the arcward increase of the wedge overburden is small, and 3) because there is less overburden on the roof thrust than on the basal thrust. However, even with high basal friction, when the slope is too large, underthrusting is inhibited and a new frontal thrust initiates [Gutscher et al., 1998]. Abandonment of the roof thrust may be favored by water content reduction and cementation as supported by the relative highvelocity layer Pa modeled along the TSC reflector (Figure 6). Our observations suggest however, that the abandonment of the roof thrust might have been first to the benefit of a midlevel décollement prior to down stepping to the basal thrust. 7.3.7. Relative Chronology of SC Deformation

[44] The scenario in Section 7.3.6 applies well to line SIS72, where step 1 (Figure 10b) would represent the construction of an initial accretionary wedge. The remainder of this wedge may have been preserved at the margin front (Figure 10a). During step 2 (Figure 10c), a weak roof thrust controlled underthrusting of TS-2 long sheet. Diffuse normal faulting deformed subducting sediment as they consolidated under increasing lithostatic load. According to the analog model by Gutscher et al. [1996], the long sheet might have cut the initial accretionary wedge along a mid-level detachment so that, during steps 2-3 (Figures 10c and 10d), wedge slivers were pushed downdip, and underplated, as Up1 duplexes. During step3, at depths of $\sim 6 \mathrm{~km}$, Riedel shears formed across the channel and initiated a mid-level décollement. Then, at the end of step 4 (Figure 10e), when the roof thrust was abandoned, the shear zone shifted downward at the downdip end of the SC thus allowing a complex contractional pattern to build on. During step 5 (Figure 10f), shear localized in the wake of fault $\mathrm{F}$ along the mid-level décollement that propagated updip. At step 6 (Figure 10g), a shear zone formed within the lower unit of the long sheet, and shear finally localized near the top of the oceanic crust. Implications of Step 5 and 6 are the initiation of the new frontal accretionary wedge and the underplating of most of the long sheet. However, pervasive contraction may carry on across the whole thickness of the SC near fault $\mathrm{F}$.

\section{Conclusions}

[45] Reprocessing line SIS-72 across the southern Ecuador margin provides evidence that the low-Vp velocity SC consists of an Upper Sequence Us interpreted as PlioPleistocene trench fill deposit overlying a lower sequence Ls inferred to be Oligo-Miocene pelagic sediment. Our structural interpretation reveals that, as trench and Nazca plate sediment was conveyed into the $\mathrm{SC}$, minor extension deformed interplate sediment, prior to the formation of a complex shear pattern, which migrated over time downward across the SC, thus forming a dynamic mega-shear zone. This pattern seemingly overprinted most of the original trench sedimentary architecture, and likely controlled fluid migration. The ensuing mega-shear zone appears bounded

Figure 10. Schematic diagram showing the multistage evolution of the SC over a $>450$ Kyr period of time. (a) Interpreted tectonic units according to the stages indicated in Figures $10 \mathrm{~b}-10 \mathrm{~g}$. Multistage scenario: (b) initial accretion develops to lower margin slope; (c) underthrusting of a long sheet along a roof thrust (red is active fault), margin slope increases, and a mid-level detachment cuts through the initial accretionary wedge [after Gutscher et al., 1996]; (d) underplated duplexes are emplaced [after Gutscher et al., 1996], Riedel shears develop as a response to shearing along the long sheet; (e) underthrusting the long sheet continues up to an end when contractional deformation associated to the basal thrust initiate; (f) the roof thrust and the Riedel shears are abandoned, shear shifts downward and propagates updip from the basal thrust at the top of the oceanic crust to along a mid-level décollement; ( $\mathrm{g}$ ) development of a shear zone at the base of the channel, then mid-level décollement thrust shifts to top of oceanic crust. Décollement thrust emerges at the seafloor, frontal accretion resumes, and the long sheet is underplated; horizontal black arrows with vertical dashed lines show the displacement of faulted-block F relative to the long sheet from Figure 10e; dotted pattern outlines area of complex internal deformation. 
by a roof and a basal thrust, and locally divided along the Us/ Ls boundary by a mid-level décollement fault that accommodates the formation of Riedel shears.

[46] Modeling groups of strong reflectors in the upper SC and at its bottom demonstrates thin low-Vp layers inferred to have a high-porosity. These layers point to a potential accumulation of high-pressured fluid in the uppermost SC, and highlight in particular the mechanical weakness of the basal thrust, which is characterized by the highest negative velocity perturbations. Relatively high-velocity perturbations modeled along the continuous roof thrust reflector support a reduced porosity and probable cementation.

[47] The formation of Riedel shears across the SC may be indicative of a specific form of basal erosion that allows capturing thin margin rocks slivers into small-scale SC structural wedges below the roof thrust. A fine scale velocity model revealed two anomalously low $\mathrm{Vp}$ patches within the SC advocating internal zones of over-pressured fluids. According to the velocity model, the foundation of the upper plate basement shows low $\mathrm{Vp}$ areas that may either indicate underplating or a damage zone possibly related to fluid released from the SC.

[48] A straightforward reconstruction of the temporal evolution of the mega-shear zone structures based on simple cinematic considerations support that frontal accretion, underthrusting of long sheets of sediment, down-stepping of the décollement and underplating are transient processes that alternate in a cyclical manner through geological times. During the ultimate cycle at the south Ecuador margin, total sediment subduction initiated more than $450 \mathrm{kyr}$ ago, interrupted $\sim 54 \pm 13 \mathrm{kyr}$ ago and was followed since then by frontal accretion. Structural consequences can be as follows:

[49] 1. Shear strain likely concentrated along a skinny SC associated with the roof thrust during underthrusting of the long sheet of sediment, although small throw normal fault affected it at shallow burial depths. Subsequently, shear strain affected gradually the entire subducting sedimentary pile: first through Riedel shears and a mid-level décollement fault at middle burial depths, and then through folds and thrust faults, which initiated at greater burial depths, possibly when the roof thrust was about to be abandoned. Contractional structures overprinted earlier structures in the deepest arcward segment of the channel and propagated up dip in the form of a basal shear zone that thinned out seaward. Ultimately, the basal thrust reached the trench seafloor and frontal accretion resumed.

[50] 2. The SC boundaries revealed highly unstable through time: (a) Rock slivers were likely ripped of the foundation of an initial accretionary wedge, pushed ahead of the underthrusting long sheet prior to be underplated as duplexes; (b) Most of the underthrust long sheet underplated when the interplate shear zone down-stepped from the roof to the basal thrust, so that the active SC has now been reduced to the basal shear zone, although shearing may still distribute across the bulk of the downdip segment of the SC landward of fault F. (c) Flakes of the uppermost subducting oceanic crust are possibly peeled of and added to the SC from below, along the active basal thrust.

[51] Acknowledgments. This work was funded by the Institut de Recherche pour le Développement (IRD), the Institut National des Sciences de l'Univers (INSU), and Institut Français pour l'Exploitation de la Mer (IFREMER), which provided ship time during the SISTEUR-2000 experiment. We are grateful to the scientific parties, captains, and crew for their support during data acquisition. We acknowledge the Associate Editor Greg Moore as well as Casey Moore and Chris Morley for their thorough reviews and very helpful comments, and we thank Stephane Operto for wise advice during data processing.

\section{References}

Adam, J., D. Klaeschen, N. Kukowski, and E. R. Flueh (2004), Upward delamination of Cascadia Basin sediment infill with landward frontal accretion thrusting caused by rapid glacial age material flux, Tectonics, 23, TC3009, doi:10.1029/2002TC001475.

Al-Yahya, K. (1989), Velocity analysis by iterative profile migration, Geophysics, 54, 718-729, doi:10.1190/1.1442699.

Aoki, Y., H. Kinoshita, and H. Kagami (1985), Evidence of a low-velocity layer beneath the accretionary prism of the Nankai Trough: Inferences from a synthetic sonic log, Deep Sea Drill. Project Initial Rep., 87, 727-735.

Avedik, F. (1993), Single bublle air-gun array for deep exploration, Geophysics, 58, 366-382.

Bangs, N., T. H. Shipley, S. P. S. Gulick, G. F. Moore, S. Kuromoto, and Y. Nakamura (2004), Evolution of the Nankai trough décollement from the trench into the seismogenic zone: Inferences from three-dimensional seismic reflection imaging, Geology, 32, 273-276, doi:10.1130/ G20211.2.

Bangs, N., G. F. Moore, S. P. S. Gulick, E. Pangborn, T. Tobin, S. Kuramoto, and A. Taira (2009), Broad weak regions of the Nankai megathrust and implications for shallow coseismic slip, Earth Planet. Sci. Lett., 284, 44-49, doi:10.1016/j.eps1.2009.04.026.

Bonnardot, M.-A., R. Hassani, E. Tric, E. Ruellan, and M. Régnier (2008), Effect of margin curvature on plate deformation in a 3-D numerical model of subduction zones, Geophys. J. Int., 173, 1084-1094, doi:10.1111/j.1365-246X.2008.03752.x.

Byrne, D. E., D. M. Davis, and L. R. Sykes (1988), Loci and maximum size of thrust earthquakes and the mechanics of the shallow region of subduction zones, Tectonics, 7(4), 833-857, doi:10.1029/TC007i004p00833.

Caine, J. S., J. P. Evans, and C. B. Forster (1996), Fault zone architecture and permeability structure, Geology, 24, 1025-1028, doi:10.1130/00917613(1996)024<1025:FZAAPS >2.3.CO;2.

Calahorrano, A. (2005), Structure de la marge du Golfe de Guayaquil (Equateur) et propriétés physiques du chenal de subduction a partir de données de sismique marine réflexion et réfraction, Ph.D. thesis, 221 pp., Université Pierre et Marie Curie, Paris.

Calahorrano, A., V. Sallares, J.-Y. Collot, F. Sage, and C. R. Ranero (2008), Nonlinear variations of the physical properties along the southern Ecuador subduction channel: Results from depth-migrated seismic data, Earth Planet. Sci. Lett., 267, 453-467, doi:10.1016/j.eps1.2007.11.061.

Campbell, C. J. (1974), Ecuadorian Andes, in Mesozoic Cenozoic Orogenic Belts: Data for Orogenic Studies, edited by A. M. Spencer, Geol. Soc. Spec. Publ., 4, 725-732.

Cloos, M., and R. L. Shreve (1988a), Subduction-channel model of prism accretion, melange formation, sediment subduction, and subduction erosion at convergent plate margins: 1. Background and description, Pure Appl. Geophys., 128(3-4), 455-500, doi:10.1007/BF00874548.

Cloos, M., and R. L. Shreve (1988b), Subduction-channel model of prism accretion, melange formation, sediment subduction, and subduction erosion at convergent plate margins: 2 . Implications and discussion, Pure Appl. Geophys., 128(3-4), 501-545, doi:10.1007/BF00874549.

Collot, J.-Y., et al. (1992), ODP Leg 134, Ocean Drill. Program, College Station, Tex.

Collot, J.-Y., K. B. Lewis, G. Lamarche, and S. Lallemand (2001), The giant Ruatoria debris avalanche on the northern Hikurangi margin, New Zealand: Result of oblique seamount subduction, J. Geophys. Res., 106, 19,271-19,297, doi:10.1029/2001JB900004.

Collot, J.-Y., P. Charvis, M. A. Gutscher, and S. Operto (2002), Exploring the Ecuador-Colombia active margin and inter-plate seismogenic zone, Eos Trans. AGU, 83(17), 189-190, doi:10.1029/2002EO000120.

Collot, J.-Y., W. Agudelo, A. Ribodetti, and B. Marcaillou (2008), Origin of a crustal splay fault and its relation to the seismogenic zone and underplating at the erosional N-Ecuador S-Colombia oceanic margin, J. Geophys. Res., 113, B12102, doi:10.1029/2008JB005691.

Coltorti, M., P. E. Baker, L. Briqueu, T. Hasenaka, and B. Galassi (1994), Petrology and geochemistry of volcanic rocks from the New Hebrides forearc region, Sites 827, 829 and 830, Proc. Ocean Drill. Program Sci. Results, 134, 337-352.

Davis, G. H., and S. J. Reynolds (1996), Structural Geology of Rocks and Regions, John Wiley, New York. 
Deniaud, Y., P. Baby, C. Basile, M. Ordonez, G. Montenegro, and G. Mascle (1999), Ouverture et évolution du Golfe de Guayaquil: Bassin d'avant arc néogène et quaternaire du sud des Andes équatoriennes, C. R. Acad. Sci. 328(3), 181-187.

Ego, F., M. Sébrier, A. Lavenu, H. Yepes, and A. Egues (1996), Quaternary state of stress in the Northern Andes and the restraining bend mode for the Ecuadorian Andes, Tectonophysics, 259, 101-116, doi:10.1016/ 0040-1951(95)00075-5.

England, P. C., and T. J. B. Holland (1979), Archimedes and the Tauern eclogites: The role of buoyancy in the preservation of exotic eclogite blocks, Earth Planet. Sci. Lett., 44, 287-294, doi:10.1016/0012-821X (79)90177-8.

Erickson, S. N., and R. D. Jarrard (1998), Velocity-porosity relationships for water-saturated siliciclastic sediments, J. Geophys. Res., 103, 30,385-30,406, doi:10.1029/98JB02128.

Gutscher, M.-A., N. Kukowski, J. Malavieille, and S. Lallemand (1996), Cyclical behavior of thrust wedges: Insights from high basal friction sandbox experiments, Geology, 24, 135-138, doi:10.1130/0091-7613 (1996)024<0135:CBOTWI>2.3.CO;2.

Gutscher, M.-A., N. Kukowski, J. Malavieille, and S. Lallemand (1998), Episodic imbricate thrusting and underthrusting: Analog experiments and mechanical analysis applied to the Alaskan accretionary wedge, J. Geophys. Res., 103, 10,161-10,176, doi:10.1029/97JB03541.

Hubbert, M. K., and W. W. Rubey (1959), Role of fluid pressure in mechanics of overthrust faulting, Geol. Soc. Am. Bull., 70, 115-166, doi:10.1130/0016-7606(1959)70[115:ROFPIM]2.0.CO;2.

Hyndman, R. D., and K. Wang (1995), The rupture zone of the Cascadia great earthquakes from current deformation and the thermal regime, J. Geophys. Res., 100, 22,133-22,154, doi:10.1029/95JB01970.

Hyndman, R. D., M. Yamano, and D. A. Oleskevich (1997), The seismogenic zone of subduction thrust faults, Isl. Arc, 6, 244-260, doi:10.1111/ j.1440-1738.1997.tb00175.x.

Jackson, C., M. Sen, and P. Stoffa (2004), An efficient stochastic Bayesian approach to optimal parameter and uncertainty estimation for climate model predictions, J. Clim., 17, 2828-2841, doi:10.1175/1520-0442 (2004)017<2828:AESBAT>2.0.CO;2.

Kanamori, H. (1986), Rupture process of subduction zone earthquakes, Annu. Rev. Earth Planet. Sci., 14, 293-322, doi:10.1146/annurev. ea.14.050186.001453.

Kelleher, J. (1972), Rupture zones of large South American earthquakes and some predictions, J. Geophys. Res., 77, 2087-2103, doi:10.1029/ JB077i011p02087.

Kendrick, E., M. Bevis, R. Smalley Jr., B. Brooks, R. B. Vargas, E. Lauria, and L. P. Souto Fortes (2003), The Nazca-South America Euler vector and its rate of change, J. S. Am. Earth Sci., 16(2), 125-131, doi:10.1016/S0895-9811(03)00028-2.

Kimura, G., E. A. Silver, and P. Blum (1997), Leg 170, Ocean Drill. Program, College Station, Tex.

Kitamura, Y., et al. (2005), Melange and its seismogenic roof décollement: A plate boundary fault rock in subduction zone: An example from the Shimanto Belt, Japan, Tectonics, 24, TC5012, doi:10.1029/ 2004TC001635.

Knipe, R. J. (1993), The influence of fault zone processes and diaganesis on fluid flow, in Diagenesis and Basin Development, Studies in Geology edited by A. D. R. Horbury and A. G. Robinson, pp. 135-154, Am. Assoc. of Pet. Geol., Tulsa, Okla.

Le Pichon, X., P. Henry, and S. Lallemant (1993), Accretion and erosion in subduction zones: The role of fluids, Annu. Rev. Earth Planet. Sci., 21, 307-331, doi:10.1146/annurev.ea.21.050193.001515.

Logan, J. M., C. A. Dengo, N. G. Higgs, and Z. Z. Wang (1992), Fabrics of experimental fault zone: Their development and relationship to mechnical behaviour, in Faut Mechanics and Transport Properties of Rocks, edited by B. Evans and T. Wong, pp. 33-67, Academic, San Diego, Calif., doi:10.1016/S0074-6142(08)62814-4.

Lonsdale, P. (1978), Ecuadorian subduction system, Am. Assoc. Pet. Geol. Bull., 62(12), 2454-2477.

Lonsdale, P. (2005), Creation of the Cocos and Nazca plates by fission of the Farallon plate, Tectonophysics, 404, 237-264, doi:10.1016/j.tecto. 2005.05.011.

Maltman, A., and P. Vannucchi (2004), Insights from the Ocean Drilling Program on shear and fluid-flow at the mega-faults between actively converging plates, in Flow Processes in Faults and Shear Zones, edited by G. I. Alsop et al., pp. 127-140, Geol. Soc., London.

Mancktelow, N. S. (1995), Nonlithostatic pressure during sediment subduction and the developement and exhumation of high pressure metamorphic rocks, J. Geophys. Res., 100, 571-583, doi:10.1029/94JB02158.

McAdoo, B. G., L. F. Pratson, and D. L. Orange (2000), Submarine landslide geomorphology, U.S. continental slope, Mar. Geol., 169, 103-136, doi:10.1016/S0025-3227(00)00050-5.
Mendoza, C., and J. W. Dewey (1984), Seismicity associated with the great Colombia-Ecuador earthquakes of 1942, 1958 and 1979: Implications for barrier models of earthquake rupture, Bull. Seismol. Soc. Am., 74(2), 577-593.

Michaud, F., J-Y Collot, A. Alvarado, E. López, and y el personal científico y técnico del INOCAR (2006), República del Ecuador, Batimetría y Relieve Continental, IOA-CVM-02-Post, Inst. Oceanogr. de la Armada del Ecuador, Guayaquil.

Mix, A. C., R. Tiedemann, and P. Blum (2003), Proceedings of the Ocean Drilling Program, Initial Reports [CD-ROM], vol. 202, Ocean Drill. Program, College Station, Tex.

Moore, J. C. (1989), Tectonics and hydrogeology of accretionary prisms: Role of the décollement zone, J. Struct. Geol., 11, 95-106, doi:10.1016/0191-8141(89)90037-0.

Moore, J. C., and D. Saffer (2001), Up-dip limit of the seismogneic zone beneath the accretionary prism of southwest Japan: An effect of diagenetic to low-grade metamorphic processes and increasing effective stress, Geology, 29, 183-186, doi:10.1130/0091-7613(2001)029<0183: ULOTSZ $>2.0 . \mathrm{CO} ; 2$.

Moore, J. C., A. Klaus, N. Bangs, and B. Bekins (1998), Proceedings of the Ocean Drilling Program, Initial Reports, vol. 171A, Ocean Drill. Program, College Station, Tex.

Moore, J. C., C. Rowe, and F. Meneghini (2007), How accretionary prisms elucidate seismogenesis in subduction zones, in The Seismogenic Zone of Sub duction Thrust Faults, edited by T. Dixon and J. C. Moore, pp. 288-325, Columbia Univ. Press, New York.

Morgan, J. K., and D. E. Karig (1995), Décollement processes at the Nankai accretionary margin, southeast Japan: Propagation, deformation, and dewatering, J. Geophys. Res., 100, 15,221-15,231.

Nelson, C. H. (1983), The Astoria fan: An elongate type fan, Geo Mar. Lett., 3, 65-70, doi:10.1007/BF02462449.

Nocquet, J. M., P. Mothes, J. Villegas Lanza, M. Chlieh, P. Jarrin, M. Vallée, H. Tavera, G. Ruiz, M. Regnier, and F. Rolandone (2010), New GPS velocity field in the northern Andes (Peru - Ecuador - Colombia): Heterogeneous locking along the subduction, northeastwards motion of the Northern Andes, Abstract G41C-04 presented at 2010 Fall Meeting, AGU, San Francisco, Calif., 13-17 Dec.

Operto, S., S. Xu, and G. Lambaré (2000), Can we quantitatively image complex structures with rays?, Geophysics, 65, 1223-1238, doi:10.1190/ 1.1444814.

Pacheco, J. F., L. R. Sykes, and C. H. Scholz (1993), Nature of seismic coupling along simple plate boundaries of the subduction type, J. Geophys. Res., 98, 14,133-14,159, doi:10.1029/93JB00349.

Park, J.-O., T. Tsuru, N. Takahashi, T. Hori, S. Kodaira, A. Nakanishi, S. Miura, and Y. Kaneda (2002), A deep strong reflector in the Nankai accretionary wedge from multichannel seismic data: Implications for underplating and interseismic shear stress release, J. Geophys. Res., 107(B4), 2061, doi:10.1029/2001JB000262.

Pelletier, B., and M. Meschede (1994), Structural style of the accretionary wedge in front of the North d'Entrecasteaux Ridge, Proc. Ocean Drill. Program Sci. Results, 134, 417-429.

Pratt, G., C. Shin, and G. J. Hicks (1998), Gauss-Newton and full Newton methods in frequency-space seismic waveform inversion, Geophys. J. Int., 133, 341-362, doi:10.1046/j.1365-246X.1998.00498.x.

Ranero, C. R., J. Phipps Morgan, K. D. McIntosh, and C. Reichert (2003), Bending, faulting, and mantle serpentinization at the Middle America Trench, Nature, 425, 367-373, doi:10.1038/nature01961.

Ranero, C. R., I. Grevemeyer, H. Sahling, U. Barckhausen, C. Hensen, K. Wallmann, W. Weinrebe, P. Vannucchi, R. von Huene, and K. D. McIntosh (2008), Hydrogeological system of erosional convergent margins and its influence on tectonics and interplate seismogenesis, Geochem. Geophys. Geosyst., 9, Q03S04, doi:10.1029/2007GC001679.

Ratzov, G., J.-Y. Collot, M. Sosson, and S. Migeon (2010), Mass-transport deposits in the northern Ecuador subduction trench: Result of frontal erosion over multiple seismic cycles, Earth Planet. Sci. Lett., 296, 89-102, doi:10.1016/j.epsl.2010.04.048.

Ribodetti, A., S. Operto, W. Agudelo, J.-Y. Collot, and J. Virieux (2011), Joint ray + born least-squares migration and simulated annealing optimization for target-oriented quantitative seismic imaging, Geophysics, 76, B1-B20, doi:10.1190/1.3554330.

Saffer, D. (2003), Pore pressure development and progressive dewatering in underthrust sediments at the Costa Rica subduction margin: Comparison with northern Barbados and Nankai, J. Geophys. Res., 108(B5), 2261, doi:10.1029/2002JB001787.

Saffer, D., and C. Marone (2003), Comparaison of smectite- and illite-rich gouge frictional properties: Application to the updip limit of the seismogenic zone along subduction megathrust, Earth Planet. Sci. Lett., 215 219-235, doi:10.1016/S0012-821X(03)00424-2. 
Saffer, D., E. A. Silver, A. T. Fisher, H. Tobin, and K. Moran (2000), Inferred pore pressures at the Costa Rica subduction zone: Implications for dewatering processes, Earth Planet. Sci. Lett., 177, 193-207, doi:10.1016/S0012-821X(00)00048-0.

Sage, F., J.-Y. Collot, and C. R. Ranero (2006), Interplate patchiness and subduction-erosion mechanisms: Evidence from depth migrated seismic images at the central Ecuador convergent margin, Geology, 34, 997-1000, doi:10.1130/G22790A.1.

Scholz, C. H. (1998), Earthquakes and friction laws, Nature, 391, 37-42, doi:10.1038/34097.

Screaton, E. (2006), Excess pore pressure within subducting sediments: Does the proportion of accreted sediment versus subducted sedimen matter?, Geophys. Res. Lett., 33, L10304, doi:10.1029/2006GL025737.

Sen, M. K., and P. L. Stoffa (1995), Global Optimization Methods in Geophysical Inversion, Elsevier Sci., New York.

Shipley, T. H., K. D. McIntosh, E. A. Silver, and P. L. Stoffa (1992), Three-dimensional seismic imaging of the Costa Rica accretionary prism: Structural diversity in a small volume of the lower slope, J. Geophys. Res., 97, 4439-4459, doi:10.1029/91JB02999.

Shreve, R. L., and M. Cloos (1986), Dynamics of sediment subduction, melange formation, and prism accretion, J. Geophys. Res., 91, $10,229-10,245$

Silgado, E. (1957), El movimiento sismico del 12 de deciembre de 1953, Bol. Soc. Geol. Peru, 32, 225-238.

Swenson, J. L., and S. L. Beck (1996), Historical 1942 Ecuador and 1942 Peru subduction earthquakes, and earthquake cycles along ColombiaEcuador and Peru subduction segments, Pure Appl. Geophys., 146(1), 67-101, doi:10.1007/BF00876670.

Taira, A., J. Hill, J. Firth, U. Brener, W. Bruckmann, et al. (1992), Sediment deformation and hydrology of the Nankai Trough accretionary prism: Synthesis of shipboard results of ODP Leg 131, Earth Planet. Sci. Lett., 109, 431-450, doi:10.1016/0012-821X(92)90104-4.

Thierry, P., S. Operto, and G. Lambaré (1999), Fast 2-D ray + Born inversion/migration in complex media, Geophysics, 64, 162-181, doi:10.1190/1.1444513.

Tichelaar, B. W., and L. J. Ruff (1993), Depth of seismic coupling among subduction zones, J. Geophys. Res., 98, 2017-2037, doi:10.1029/ 92JB02045.

Tobin, H., and D. Saffer (2009), Elevated fluid pressure and extreme mechanical weakness of a plate boundary thrust, Nankai Trough subduction zone, Geology, 37, 679-682, doi:10.1130/G25752A.1.

Tobin, H., P. Vannucchi, and M. Meschede (2001), Structure, inferred mechanical properties, and implications for fluid transport in the décollement zone, Costa Rica convergent margin, Geology, 29, 907-910, doi:10.1130/0091-7613(2001)029<0907:SIMPAI>2.0.CO;2.

Trenkamp, R., J. N. Kellogg, J. T. Freymueller, and H. P. Mora (2002), Wide plate margin deformation, southern Central America and northwestern South America, CASA GPS observations, J. S. Am. Earth Sci., 15, 157-171, doi:10.1016/S0895-9811(02)00018-4.

Tsuru, T., J. Park, S. Miura, S. Kodaira, Y. Kido, and T. Hayashi (2002), Along-arc structural variation of the plate boundary at the Japan Trench margin: Implication of interplate coupling, J. Geophys. Res., 107(B12), 2357, doi:10.1029/2001JB001664.

Ujiie, K., T. Hisamitsu, and A. Taira (2003), Deformation and fluid pressure variation during initiation and evolution of the plate boundary décollement zone in the Nankai accrtionary prism, J. Geophys. Res., 108(B8), 2398, doi:10.1029/2002JB002314.

Vannucchi, P., and H. Tobin (2000), Deformation structures and implications for fluid flow at the Costa Rica convergent margin, ODP Sites 1040 and 1043, Leg 170, J. Struct. Geol., 22, 1087-1103, doi:10.1016/ S0191-8141(00)00027-4.

Vannucchi, P., F. Remitti, and G. Bettelli (2008), Geological record of fluid flow and seismogenesis along an erosive subducting plate boundary, Nature, 451, 699-703, doi:10.1038/nature06486.

Vannucchi, P., J. Phipps Morgan, F. Sage, J.-Y. Collot, and F. Remitti (2011), The upper subduction channel from subduction to seismogenesis, paper presented at Nature of the plate interface in Subduction Zones, W. Alps: Task Force IX Workshop, Int. Lithosphere Program, Piemonte, Italy, 2-7 July.

von Huene, R., D. Klaeschen, and B. Cropp (1994), Tectonic structure across the accretionary and erosional parts of the Japan trench margin, J. Geophys. Res., 99, 22,349-22,361, doi:10.1029/94JB01198.

von Huene, R., C. R. Ranero, and P. Vannucchi (2004), Generic model of subduction erosion, Geology, 32, 913-916, doi:10.1130/G20563.1.

Vrolijk, P. (1990), On the mechanical role of smectite in subduction zones, Geology, 18, 703-707, doi:10.1130/0091-7613(1990)018<0703: OTMROS $>2.3 . \mathrm{CO} ; 2$.

Wang, K., and Y. Hu (2006), Accretionary prisms in subduction earthquake cycles: The theory of dynamic Coulomb wedge, J. Geophys. Res., 111, B06410, doi:10.1029/2005JB004094.

Warner, M. (1990), Absolute reflection coefficients from deep seismic reflections, Tectonophysics, 173, 15-23, doi:10.1016/0040-1951(90) 90199-I.

Winter, T., J. Avouac, and A. Lavenu (1993), Late Quaternary kinematics of the Pallatanga strike slip fault (central Ecuador) from topographic measurements of displaced morphological features, Geophys. J. Int., 115, 905-920, doi:10.1111/j.1365-246X.1993.tb01500.x.

Witt, C., J. Bourgois, F. Michaud, M. Ordoñez, N. Jimenez, and M. Sosson (2006), Development of the Gulf of Guayaquil (Ecuador) during the Quaternary as an effect of the North Andean block tectonic escape, Tectonics, 25, TC3017, doi:10.1029/2004TC001723.

W. Agudelo, ECOPETROL, Instituto Colombiano del Petróleo, Km 7 Via Piedecuesta, Piedecuesta, Santander 007, Colombia.

J.-Y. Collot and A. Ribodetti, Université de Nice Sophia-Antipolis, Institut de Recherche pour le Développement (UR082), Observatoire de la Côté d'Azur, Géoazur, La Darse B.P. 48, F-06235 Villefranche-sur-Mer Cedex, France. (collot@geoazur.obs-vlfr.fr)

F. Sage, Université de Nice Sophia-Antipolis, Université Pierre et Marie Curie, Observatoire de la Côte d'Azur, Géoazur, La Darse B.P. 4806235 Villefranche-sur-Mer Cedex, France. 